\title{
'Her future is marriage': Young people's attitudes towards gender roles and the gender gap in Egypt
}

Maia Sieverding

Population Council

Rasha Hassan

Population Council

Follow this and additional works at: https://knowledgecommons.popcouncil.org/departments_sbsr-pgy

Part of the Demography, Population, and Ecology Commons, Family, Life Course, and Society Commons, Gender and Sexuality Commons, and the International Public Health Commons How does access to this work benefit you? Let us know!

\section{Recommended Citation}

Sieverding, Maia and Rasha Hassan. 2016. "'Her future is marriage': Young people's attitudes towards gender roles and the gender gap in Egypt." Cairo: Population Council. 


\section{'HER FUTURE IS MARRIAGE': \\ Young People's Attitudes towards Gender Roles and the Gender Gap in Egypt}

Maia Sieverding and Rasha Hassan 


\section{porularon Pronnch \\ Ideas. Evidence. Impact.}

The Population Council confronts critical health and development issues-from stopping the spread of HIV to improving reproductive health and ensuring that young people lead full and productive lives. Through biomedical, social science, and public health research in 50 countries, we work with our partners to deliver solutions that lead to more effective policies, programs, and technologies that improve lives around the world. Established in 1952 and headquartered in New York, the Council is a nongovernmental, nonprofit organization governed by an international board of trustees.

Population Council

One Dag Hammarskjold Plaza

New York, NY 10017

Population Council/Egypt

59 Misr-Helwan Agricultural Road, Maadi

PO Box 168, Maadi

Cairo, Egypt 11431

Tel. +20 225255968

Fax: +2022525 5962

\section{popcouncil.org}

Suggested citation: Maia Sieverding and Rasha Hassan. 2016. “Her Future is Marriage':Young People's Attitudes towards Gender Roles and the Gender Gap in Egypt" Cairo: Population Council.

The opinions expressed herein are those of the authors and do not necessarily reflect the views of the initiative supporters.

Photo credit: Gehad Abaza. The cover photo was taken during the qualitative field work conducted in Manshiet Nasser under the Survey of Young People in Egypt project in September 2016.

Any part of this publication may be photocopied without permission from the Population Council provided that copies are distributed without charge and that full source citation is provided. The Population Council would appreciate receiving a copy of any materials in which the text is used.

(C) 2016 The Population Council, Inc. 


\section{Table of contents}

1. INTRODUCTION . . . . . . . . . . . . . . . 1

2. METHODS............................. . . .

2.1 The Survey of Young People in Egypt $\ldots \ldots \ldots 3$

2.2 Qualitative data.................... 3

3. THE ROLE OF WOMEN IN THE PUBLIC SPHERE . . . . 5

3.1 Girls' right to education. ................ 5

3.2 Women's access to employment .......... 8

3.3 Sexual harassment................. 9

4. GENDER EQUALITY IN THE HOUSEHOLD . . . . . . . . 14

4.1 Views on domestic violence .............. 14

4.2 Household decision-making and authority ... . . 17

5. PERSONAL STATUS LAW AND LEGAL EQUALITY. . 21

5.1 Women's right to a divorce .............. 21

5.2 Women's right to inheritance............... 24

6. CONCLUSIONS AND POLICY RECOMMENDATIONS..27

REFERENCES ....................... 30

APPENDIX 1: SYPE SURVEY QUESTIONS ON GENDER

ROLE ATTITUDES . . . . . . . . . . . . . . . . 32

APPENDIX 2: FULL TEXT OF QUALITATIVE VIGNETTES

(ARABIC AND ENGLISH) ................... 34 



\section{Introduction}

The gender gap in men's and women's outcomes in Egypt has been well documented. In the most recent Global Gender Gap Report, Egypt ranked $136^{\text {th }}$ out of 145 countries in terms of progress towards achieving gender equality in economic opportunity, educational attainment, health and survival, and political empowerment. Egypt performed particularly poorly in the economic and political domains, in which it ranked $135^{\text {th }}$ and $136^{\text {th }}$, respectively, and somewhat better in education $\left(115^{\text {th }}\right)$ and health and survival $\left(97^{\text {th }}\right)$. Egypt's performance, which has changed little since it was first included in the Gender Gap Index in 2006, placed it near the bottom of the rankings of lower middle-income countries, and behind other countries in the Middle East and North Africa such as Kuwait, Tunisia and Oman (World Economic Forum 2015). This disappointing outcome points to the importance of closing the gender gap across a range of dimensions as part of Egypt's transitional agenda after the Arab Spring.

Despite growing international attention to gender equality, the gender gap also persists among young people in Egypt. Young Egyptian women are disadvantaged in many areas of life relative to their male peers, including in the public sphere, household dynamics, and in the legal system. Yet although the numerous dimensions of the gender gap in Egypt have been explored in terms of young people's outcomes, relatively little research has examined how young people think about differences in men's and women's roles in society and at home, and why they hold the beliefs that they do. In this report, we therefore focus on new quantitative and qualitative data that examines young people's gender role attitudes. We use the term "gender role attitudes" to indicate individuals' support for the notion of separate spheres for men and women in any domain, including the labor market, household and civic life (Davis and Greenstein 2009). We refer to support for separate spheres in any of these domains as "conservative" gender role attitudes, and support for equal roles for men and women as "egalitarian" attitudes.

International research has shown that gender role attitudes are associated with outcomes including women's labor force participation and earnings (Cunningham et al. 2005; Corrigall and Konrad 2007; Farré and Vella 2013), the timing of transitions to marriage and parenthood (Cunningham et al. 2005; Corrigall and Konrad 2007), the division of childcare and household labor between spouses (see Davis and Greenstein 2009 for a review), and gender-based violence, although through complex mechanisms (Atkinson, Greenstein, and Lang 2005). At the same time, gender role attitudes may change over the transition to adulthood, becoming more conservative or more egalitarian as young people are exposed to new life situations (Fan and Marini 2000; Cunningham et al. 2005). The period of adolescence and young adulthood is therefore an important one for understanding how gender role attitudes in a society may or may not be changing.

Data from national surveys conducted by the Population Council, including the Survey of Young People in Egypt that is the basis for this report, have demonstrated that gender role attitudes among young people are conservative, with high levels of support for the idea of separate spheres across a range of domains (Mensch et al. 2003; Population Council 2010; Salemi and Rashed 2015). However, a more detailed analysis of change in gender role attitudes over the transition to adulthood, and, critically, why young people do or do not support separate spheres for men and women, can shed further light on this important aspect of the gender gap in Egypt. Young people's attitudes towards gender roles are likely to influence not only their own decisions, but also the social norms that contribute to shaping the gender gap. For example, cross-nationally, egalitarian gender role attitudes are associated with differences in women's employment rates (Fortin 
2005), demonstrating the complex causality between social norms and women's - as well as men's - outcomes. A better understanding of how young people's attitudes are formed in Egypt and in what areas youth support or oppose greater gender equality is therefore an important step in designing programs and policies that work towards a more gender equal future.

We organize our discussion of young people's gender role attitudes in this report into the public, household and legal domains. After an overview of the study data and methods in Section 2, in Section 3 we begin with a discussion of women's roles in the public sphere, specifically the areas of education, employment and sexual harassment in public spaces. In Section 4, we turn to gender relations within the household, addressing decision-making and obedience between spouses and attitudes towards domestic violence. We discuss women's legal rights in Section 5, covering young people's knowledge of and attitudes towards women's rights in divorce and inheritance. In Section 6, we summarize the overall findings and provide recommendations for programs and policies that promote gender equality. 


\section{Method}

We examine youth gender role attitudes in Egypt through a combination of quantitative and qualitative data. The quantitative data, from the nationally representative Survey of Young People in Egypt (SYPE) 2009 and 2014, provides for a broad overview of youth gender role attitudes throughout the country and among different subpopulations of youth. The qualitative data complements this analysis by allowing us to gain a more in-depth view of how young people think about men and women's roles in society and why they hold these beliefs.

\subsection{The Survey of Young People in Egypt}

In 2009, the Population Council conducted the Survey of Young People in Egypt, a nationally representative survey that generated a unique and comprehensive source of data on the situation of young cohorts in Egypt. The SYPE captured 15,029 young people aged 10 to 29 from 11,372 households, thus encompassing both "youth" and "adolescents." The purpose of this age range was to track young people throughout the complete duration of their transition to adulthood, allowing for an extended period to account for the many changes that occur during this key period of life (for more details see Population Council 2010).

Given the unprecedented series of political changes that have occurred in Egypt since 2009, the Population Council then designed and implemented the second wave of SYPE in 2013/2014, in order to observe young people's outcomes and attitudes during this transitional period. The second round of data for the SYPE re-interviewed the same sample of young people who were interviewed in 2009, successfully tracking 10,916 (72.6\%) of those same individuals (now aged $13-35$ ). A full description of the SYPE panel can be found in Roushdy and Sieverding, eds. (2015).

The SYPE panel provides a rich source of key information on adolescents and youth living in Egypt before and after the revolution, including education, employment, migration, family formation, health, and civic and political participation. Furthermore, SYPE includes extensive modules on young people's gender role attitudes, opinions on domestic violence and divorce, and social values. SYPE also contains a great deal of information on the demographic and socioeconomic characteristics of respondents' households, allowing us to examine variation in youth gender role attitudes across a range of background characteristics. The gender role attitudes questions were only administered to young people who were age 15 and older in 2009. Therefore, in this report, our analysis is restricted to the sample of 6,199 young people who are included in the SYPE panel and answered the gender role attitudes questions in both years. This sample includes 2,803 young men, and 3,396 young women, $60 \%$ of whom lived in rural areas, $31 \%$ in urban areas, and $9 \%$ in informal urban areas.

We use measures of youth gender role attitudes from four different opinion indices in SYPE. To assess attitudes towards gender roles in the public and private sphere, we use a series of questions that asked youth about gender equality in education, employment, and the household. SYPE also investigated youths' attitudes towards domestic violence by asking respondents whether a man is justified in beating his wife under a range of circumstances, ranging from burning the food to refusing to have sex with her husband. Finally, SYPE included two sets of questions probing youth's opinions on situations in which a woman is justified in asking for a divorce and when a man is justified in divorcing his wife, respectively. We also analyze a question about women's right to inheritance. The full text of all the SYPE gender role attitude questions used is provided in Appendix 1. Where possible, we compare change in youth attitudes from 2009 to 2014 . However, because the answer choices for some of the questions measuring gender attitudes changed between the two survey waves, this is not possible for all topics.

\subsection{Qualitative data}

In early 2016, the Population Council conducted a qualitative companion study to the SYPE in informal 
urban areas in the Greater Cairo Metropolitan Area. The spread of informal areas and growth in the number of their inhabitants is an important population trend within Cairo and across Egypt. Thus, while not representative of youth in Egypt overall, youth in informal urban areas are an important sub-population for understanding trends in attitudes among young people. The qualitative study team purposively selected three informal areas within Greater Cairo that had experienced varying levels of intervention by government and Non-Governmental Organizations (NGOs). We collaborated with a local NGO in each area in order to identify respondents to participate in in-depth interviews that covered a range of topics about young people's lives in the 'ashwaiyyat.

As part of the interview, young people were asked about gender attitudes through a series of vignettes, or short scenarios, focusing on specific aspects of gender relations in the Egyptian context, including girls' education, domestic violence, sexual harassment, divorce and inheritance. Vignettes are a useful interviewing technique for probing attitudes and social norms, particularly around topics that may be sensitive, because they allow respondents greater flexibility in deciding whether they want to speak about personal experiences related to the scenario, while also encouraging them to think beyond their personal circumstances. At the same time, vignettes may be more engaging for young people because they are discussing scenarios that are relevant to their own lives (Barter and Renold 2000; Schoenberg and Ravdal 2000). As all respondents in the qualitative sample reacted to the same vignette, this format also allows for easier comparison of attitudes across interviewees. The full text of the vignettes, in English and the original Egyptian Colloquial Arabic, is presented in Appendix 2.

Respondents for the qualitative interviews were selected to achieve variation in socio-demographic characteristics including education, age, religion and exact place of residence within the study area. Eight young men and eight young women were interviewed in each area, for a total of 48 interviews. The characteristics of the qualitative interview sample are summarized in Table 1.

TABLE 1: Characteristics of the qualitative interview sample

\begin{tabular}{|c|c|c|}
\hline & WOMEN & MEN \\
\hline \multicolumn{3}{|l|}{ Age group } \\
\hline $18-24$ & 11 & 13 \\
\hline $25-29$ & 12 & 10 \\
\hline Missing & 1 & 1 \\
\hline \multicolumn{3}{|l|}{ Education } \\
\hline Preparatory or less & 6 & 7 \\
\hline Secondary & 8 & 11 \\
\hline Technical institute & 3 & 2 \\
\hline University & 7 & 4 \\
\hline \multicolumn{3}{|l|}{ Marital status } \\
\hline Never married & 11 & 18 \\
\hline Engaged & 2 & 5 \\
\hline Married & 9 & 1 \\
\hline Widowed/divorced & 2 & 0 \\
\hline \multicolumn{3}{|l|}{ Employment status } \\
\hline Out of labor force & 10 & 0 \\
\hline Unemployed & 2 & 2 \\
\hline Wage worker & 7 & 16 \\
\hline Self employed & 1 & 5 \\
\hline Other & 4 & 1 \\
\hline Total & 24 & 24 \\
\hline
\end{tabular}




\section{The role of women in the public sphere}

We begin our analysis with a discussion of young people's views on the role of women in the public sphere. First we address young people's views on girls' right to education, as well as their understandings of the value of boys' and girls' education. We then turn to women's access to employment and expectations around whether or not women will work. We conclude the section with a discussion of sexual harassment, focusing in particular on young people's views of the causes of harassment and who is responsible for the occurrence of sexual harassment.

\subsection{Girls' right to education}

One area in which young women have made substantial gains in Egypt is education. Although in some regions of the country girls continue to be at greater risk of never attending school than boys, the gender gap in education has closed rapidly over recent cohorts. Whereas $26.2 \%$ of women aged 30 - 34 in SYPE had never attended school, compared to $10.2 \%$ of men, among those aged 18 and younger only $3.1 \%$ of girls and $4.0 \%$ of boys had never attended school (Krafft 2015). The gender gap in higher education has also closed; young women in Egypt are now as likely to obtain a university degree as young men (UNDP and INP 2010).

FIGURE 1: Young people's agreement with the statement "Educating boys is more important than educating girls", by gender and educational attainment, 2014

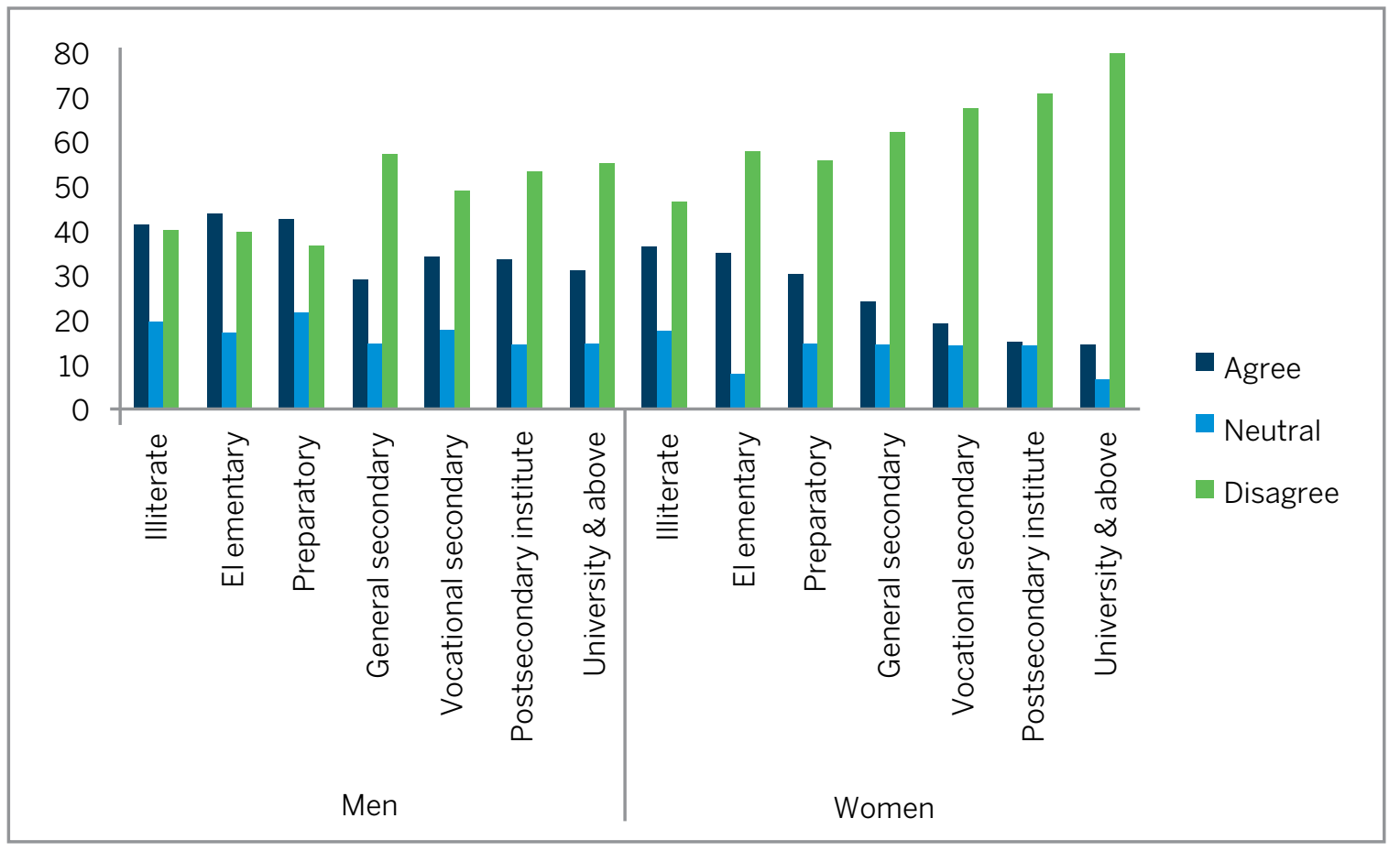


Education was also the area in which young people in both SYPE and the qualitative sample demonstrated the most egalitarian gender attitudes. Two-thirds of young women and $48 \%$ of young men surveyed in SYPE disagreed with the statement that "educating boys is more important than educating girls." Although there was little variation in responses to this statement by residency in rural, urban or informal areas, support for gender equality in education increased substantially with young people's own educational attainment. As shown in Figure 1, educational attainment was more strongly associated with support for equality in educational opportunity among young women; whereas $46.6 \%$ of illiterate young women disagreed with the statement, this rose to $79.2 \%$ among those with a university education. Among young men, disagreement with the statement hovered around 40\% among those with a preparatory education or less, and around $50 \%$ among those with a secondary education or higher.

The qualitative respondents also expressed support for girls' education when presented with the first vignette, in which a father wants to withdraw his 16-year-old daughter Laila from school in order to marry her to a man in his 30s (see Appendix 2). The large majority of respondents, both men and women, agreed with Laila's position of refusing the marriage. The most common reason given for supporting Laila's refusal was the importance of her education.

She is right, because she likes school and she's good at it, why wouldn't we give her the opportunity? If I had a sister in that situation, I would do anything so that she can learn because I know that as long as she puts her mind to it she'll learn and she'll become something.

- Young man, age 26, never married, preparatory education or less
She is right, education is the most important thing now. If you study well you will take a degree, and you'll be able to work, make yourself responsible, [and] make yourself something, but after marriage you'll sit at home and you won't be able to work

- Young woman, age 27, married, secondary education

On the other hand, the age of the potential spouses was another factor that led some respondents to agree with Laila's refusal of the marriage. Most of these respondents saw Laila as too young to marry, but a few women respondents also mentioned the age gap between Laila and the prospective husband. A few other respondents suggested that she could marry and continue her education at the same time, because marriage is important for a girl. Nevertheless, respondents were nearly unanimous in saying that Laila's father should not force her to marry against her wishes.

Although supportive of girls continuing their education over early marriage, when presented with the scenario in which a couple must choose between sending their son or their daughter to general secondary school, ${ }^{1}$ qualitative respondents expressed different understandings of why schooling is important for boys versus girls. About half of the young men and more than half of the young women said that the parents should let the boy continue with his schooling. The main reason respondents gave for this choice was that the boy will need to work, so education will benefit him in the labor market, whereas the

1 General secondary education in Egypt is expensive due to the need to take private lessons in order to pass high-stakes exams that determine university placements (Assaad and Krafft 2015). 
girl's future lies in marriage ("maseerha el gawaz") regardless of how much education she eventually obtains. Several of the women respondents also specifically noted that education would help the boy to get a good job, which would help him to marry.

The boy, because the girl in the end will stay home and take care of her house, her husband and her kids. She'll be a housewife. But the boy might find a job with his education, with his diploma, and then he might be able to marry well.

- Young woman, age 28, married, secondary education

In contrast to the consistent labor market explanations that respondents gave for the boy to continue his education, the women respondents and few men respondents who said that the parents should let the girl continue her schooling gave more varied reasons. A few young women noted that the girl would have better marriage opportunities with higher education. Several young people of both genders said that higher education would give the girl more employment opportunities - often in association with the idea that women tend to have or are preferred for office jobs whereas young men can work in any field.

\section{They'll choose the girl because the} boy can find work anywhere, but the girl has to have higher education so that she can marry well.

- Young woman, age 25, never married, university education
A number of respondents also reasoned that girls tend to be better in school and are more disciplined, whereas boys do not study as much.

Girls are better in school than boys, and with education she might have more opportunity to find a job than

a boy.

- Young woman, age 20, engaged, technical post - secondary education

Related to the idea that girls may do better in school, about a third of the young men (but none of the women respondents) said that they would consider the two children's abilities and interest in school, and use this as the basis for determining who should continue.

That's difficult. I guess we'd sit, me and my wife and the two kids - I'm telling you what I'd do if I were in his place - we'd sit the four of us and see which one [child] is more interested in continuing.

- Young man, age 22, never married, secondary education

The one that's better in school is the one that should continue. If the girl is clever, she continues, if the boy is clever, he continues. It's not ok that I keep the girl at home and send the boy because he's a boy, even if he's not good at school.

- Young man, age 21, never married, preparatory education or less 
That it was primarily young men who suggested considering the children's ability is an encouraging sign that their generally more conservative attitudes towards girls' education may begin to move closer to those of their female peers.

Education was thus one of the areas in which young people expressed the strongest support for gender equality, and their support of girls' education over early marriage is particularly encouraging for closing the gender gap in ever-enrollment in school that persists in some regions of the country. Yet at the same time, young people's explanations for why education is important for girls focused on the role of education in helping girls to achieve better socioeconomic outcomes. While this dimension of education is no doubt important, it was also natural for many respondents - when asked to chose between girls' and boys' education - to prioritize the boy because his economic outcomes in particular were seen as more fundamental to the family unit. This prioritization of boys' education was closely related to the expectation that women will not work, which we discuss in greater detail in the next section, and was stronger among young men. Almost none of young people's discussions around girls' education focused on the idea of education as a right, or a form of empowerment that is important for her own personal development. If wider support for gender equality in education is to be achieved, and to serve as a basis for support of equality in other domains, a more rights-based understanding of girls' education is important to achieve.

\subsection{Women's access to employment}

Labor force participation rates among women in Egypt are among the lowest in the world (UNDP 2006), and have been declining over time among educated women in particular (Assaad and El Hamidi 2009). Only 15\% of young women aged 15 - 35 were in the labor force as of 2014. Young women also suffer from higher unemployment rates than young men, are less likely to own their own businesses, and employed women tend to be concentrated in certain sectors (Roushdy and Selwaness 2015). In addition to structural barriers, social norms regarding appropriate employment for women (Barsoum 2004; Assaad 2007) and associated family involvement in decisions about whether and where women can work (Sieverding 2012) restrict their economic opportunities.

Findings from SYPE and the qualitative study suggest that conservative norms regarding women's employment persist among Egypt's young people. SYPE respondents demonstrated substantially more conservative attitudes towards women's employment compared to their education. Seventy percent of young men and 55\% of young women agreed that when employment opportunities are scarce, men should have priority in getting jobs over women. As we might expect, young people's own employment experiences had some association with their views on this question, particularly for young women. Young women who were in the labor force - whether employed or unemployed - were more likely to disagree with giving men priority in obtaining jobs (Figure 2). Nevertheless, over half of employed women still agreed that men should have priority in obtaining jobs when jobs are scarce. Among young men, the unemployed were most likely to agree with giving men priority in obtaining jobs, suggesting that their own labor market struggles may influence their views on women's work. 
FIGURE 2: Young people's agreement with the statement "When employment opportunities are scarce, men should have priority in getting jobs over women", by gender and employment status, 2014

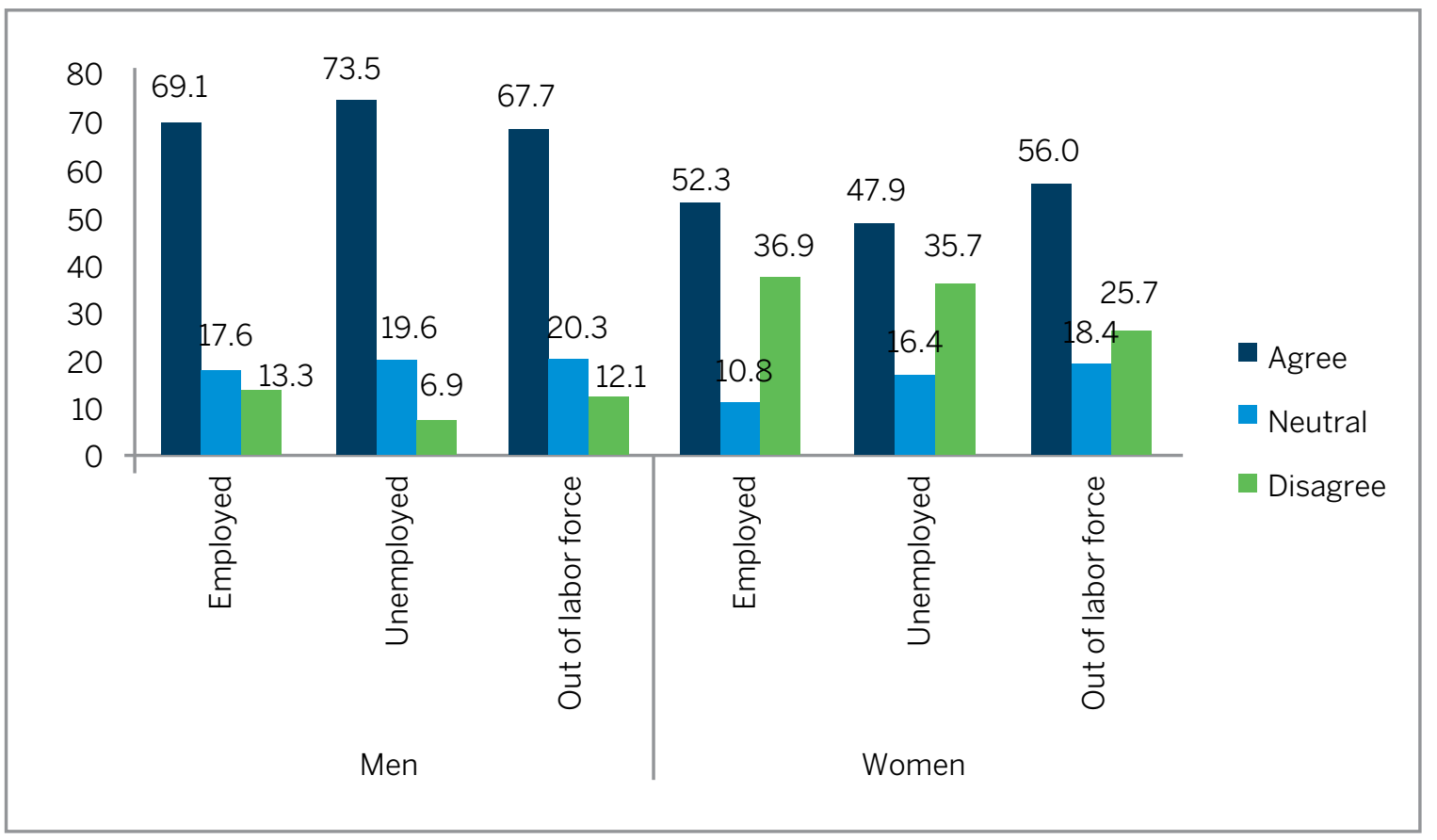

Young people in informal areas were more likely to disagree (31.4\%) with men having priority in obtaining jobs as compared to their peers in rural (17.8\%) and urban (20.6\%) areas. Nevertheless, the qualitative respondents' discussions of boys' versus girls' education demonstrated an underlying expectation of a male breadwinner, female homemaker household model that accords with the SYPE data.

\section{The boy will have more of a role} in society, the boy is the basis in that he goes out to work, strives to provide for the family and sees to the needs of the home, and his mother and his father. He might provide for several households. The girl, her future will be marriage, and she can marry with a degree but a regular degree, that she can read and remember and write, teach her children. But the girl isn't the basis for the house in terms of work.

- Young woman, age 28, married, secondary education

Because when the boy enters general secondary he'll get a university degree and find a good job opportunity... and he'll be the provider of a family. The girl won't be the provider of a family, her future is that she gets married. Whether she works or not there's someone providing for her.

- Young man, age 25, engaged, university education 
In this context in which women's work is not viewed as essential to the household economy, it is not surprising that the majority of both respondents in the SYPE supported the idea of men having priority in obtaining jobs. The qualitative data suggests that the expectation of highly gendered household roles may contribute to low rates of labor force participation among young women, which in turn reinforces the male breadwinnerfemale homemaker model. This model of gender relations, which many young people of both genders expressed acceptance of and support for, was also integral to their attitudes in a number of other domains, including their understanding of the importance of girls' education and, as discussed below, household decision-making and authority.

\subsection{Sexual harassment}

One of the ways in which women's movement within public spaces, including schools, places of employment and transport, is contested in Egypt is through the phenomenon of sexual harassment. Sexual harassment has been shown to be a generalized problem in Egypt; nationally, nearly $40 \%$ of young women reported having been sexually harassed in 2014, including $60 \%$ of those in informal urban areas (Ismail, Abdel-Tawab, and Sheira 2015). Women's experience of harassment has been found to be as high as 95\% in targeted surveys in Cairo (Harassmap 2014). Women have reported the negative psychological effects of harassment (Egyptian Center for Women's Rights 2008; Harassmap 2014), and harassment or fear of exposure to harassment may contribute to women's reduced mobility and participation in public spaces. In an important step towards combating this problem, sexual harassment was specified as a punishable offense in the Egyptian penal code in 2014. The law specifies a minimum sentence of six months imprisonment, a fine, or both for someone convicted of harassment, with additional measures for repeat offenders. Importantly, the law defined harassment to include gestures and speech as well as actions, and to include harassment by telephone. However, the law is widely considered to be poorly enforced, and few cases of harassment have ever been prosecuted.

Young people in Egypt demonstrate substantial levels of tolerance for sexual harassment, with $60 \%$ ( $63 \%$ of young men and $56 \%$ of young women) agreeing with the statement that "girls/ women who are harassed deserve it if they are dressed provocatively." An additional 14\% of young people of both genders said they were "neutral" with regards to the statement. Young people in informal areas were the most disapproving of sexual harassment, with $47.8 \%$ disagreeing with the statement, compared to $31.0 \%$ of urban and $19.6 \%$ of rural youth (Figure 3 ).

FIGURE 3: Young people's agreement with the statement "Girls/women who are harassed deserve it if they are dressed provocatively", by residency, 2014

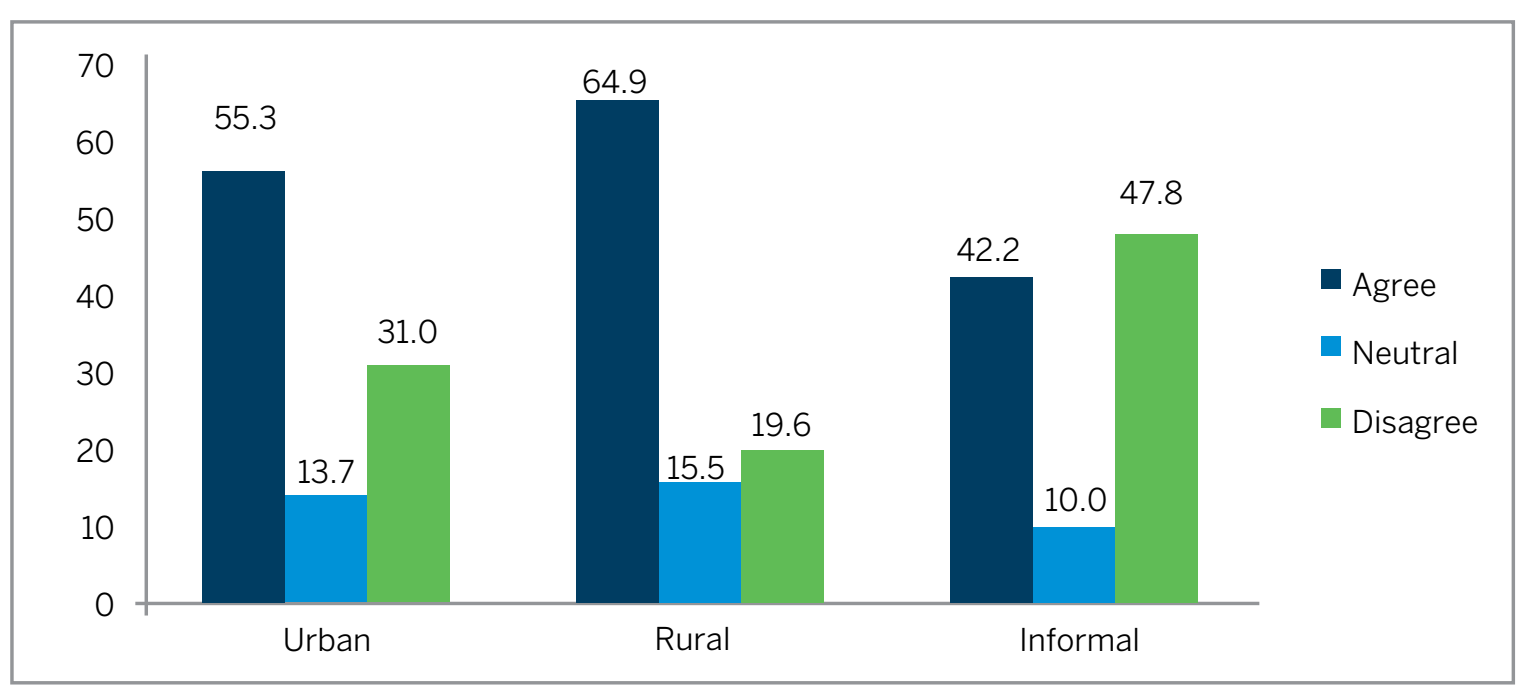


Even though youth in informal areas were the most disapproving of sexual harassment, many of their responses to the qualitative vignettes similarly supported the idea that some women who are subjected to sexual harassment "deserve it." Qualitative respondents were posed the story of a girl, Suha, who is exposed to various types of harassment on her way to work, and asked their opinions of the actions of the girl, the harasser, and the bystanders to the incident (Appendix 2).

Respondents were first asked their opinion of the girl's lack of response to the harassment, which the majority of both men and women disagreed with. However, men and women had differing opinions as to the actions that Suha should have taken. Young women said that Suha should have hit the harasser, since it was necessary to rebuke what he had done, and then file a report at the police station and ask for help from the bystanders who saw the man harass her. Several respondents justified such reactions by saying that keeping quiet would only encourage further acts of harassment, whether by the same man or another.

She should have done anything, like, he touched her, then [she should] hit him, if someone harasses her verbally, then maybe I wouldn't pay attention and not do anything, but that he touched her and she was quiet...no, it might make everyone try to touch her afterwards.

- Young woman, age 25, married, technical post - secondary education

Young men, in contrast, while they agreed that Suha should rebuke her harasser, were divided between saying that she should ask for help from the bystanders and saying that she should file a report at the police station.

\section{If in that moment she yells at him, and gathers the people [bystanders] and gets them to hit him, then she's respectable. But if she let it go and went and didn't do anything, then she'll make him do it again. \\ - Young man, age 18, never married, secondary education}

Nevertheless, there were some young people who said that Suha did the right thing in not responding to the harassment. Young women most commonly said that keeping quiet would make it less likely that bystanders would blame Suha for any altercation with the harasser, which could cause her more problems. Several also noted that the harasser might do something else to her if she responded and the situation would escalate.

\author{
As a people here, in a popular \\ [sha'abi] neighborhood, you can't \\ say anything because if you do then \\ you're damaging your reputation. \\ - Young woman, age 19, never \\ married, university education \\ I can't really blame her, that she \\ didn't say anything, because there \\ are a lot of girls who are afraid \\ to speak up, she's afraid of him, \\ because he might hit her if she \\ started an argument with him. \\ - Young woman, age 19, never \\ married, university education
}

Young men who said that Suha was right to keep quiet mostly said that her lack of reaction might be an indication that she caused the harassment or wanted it to happen to her. 
No she wouldn't be afraid [to react] because she's among people... but if she's quiet it's because she likes it.

- Young man, age 18, engaged, secondary education

A few respondents also said that harassment was something very common, so it is better for girls not to react to it.

When asked about why the man harassed Suha, the majority of respondents of both genders attributed his actions to bad personal character, feelings of inferiority and not being respectable, whether in terms of sexual desire (often phrased in terms of being unmarried), poor upbringing or lack of respect for others.

\section{He might be unmarried...you might want to buy a pair of pants but you don't have the money, but you pass by the store every day just to be near to them and touch them even if you won't buy them. In his mind he [the harasser] got close to her body when he touched her and that might have satisfied him mentally. \\ - Young man age 21, never married, preparatory education or less}

Several respondents also suggested that the man might have been drinking or taking drugs, which led him to harass Suha without fully realizing what he was doing.

On the other hand, a number of respondents, both men and women, said that Suha probably caused the man to harass her due to her own actions or comportment. These respondents said that her dress, eye contact, or way of walking in the street led the man to think she wanted to be harassed.
She should respect herself and wear decent clothes...that she's going around wearing these tight clothes, am I supposed to look down at the ground? I'Il look despite myself, I'll harass her despite myself. If there was good upbringing at home and they were paying attention at home, would she be going out like that?

- Young man, age 23, engaged, secondary education

Finally, a few respondents said that the incident occurred due to the fact that there was no deterrent to prevent the man from harassing a girl, whether that deterrent would be legal or social, or consist of actions by the girl herself or the bystanders who witnessed the event.

When I was a certain age we used to go to Fustat Park, Azhar Park, sometimes I would see people making big circles around girls, touching them in certain places on their bodies. Why did we do this? No one used to stop us, just if someone from security - I don't mean that security is on every street, but if someone from the Park security had come we would have run... and also no one ever told us that what we were doing was wrong, we were playing....

- Young man, age 22, never married, secondary education

These conflicting views on the causes of harassment were also reflected in respondents' discussions of who was responsible for the incident that happened to Suha, and what should have been done about it. Although about half of both men 
and women respondents said that the harasser himself was responsible, there were substantial gender differences in the other responsible parties mentioned. Several young women said that the bystanders were responsible, saying that the bystanders should have protected the girl and taken action against the harasser, such as yelling at him, keeping him away from the girl, or hitting him, or helping the girl to file a report at the police station. However, other respondents attributed the bystanders' lack of action to Suha's own silence, saying that because she did not ask for help, the bystanders may have thought that she wanted to be harassed.

\section{It might be that they did the wrong} thing because they didn't see any reaction from her, I imagine that if she had reacted in any way everyone one have stopped and spoken to him, but when she was quiet everyone else was too. They should have turned around, [and told him] that kind of thing is wrong, and we see you.

- Young woman, age 27, married, secondary education

A number of young women also blamed the lack of any legal consequence for harassment and insufficient police presence on the streets to enforce any law and protect women in public spaces.

If the harassment law was applied, no one would harass anyone else. If every person [male] who harassed another person [female] was punished, no one would do that anymore.

- Young woman, age missing, widowed, preparatory education or less
Only a few young men blamed law enforcement or bystanders for the situation. Young men, were more likely to say that Suha herself was the primary responsible party for what happened, something that was said by only a few women respondents. Nevertheless, about a third of both young men and women said that girls had to be responsible for protecting themselves from harassment by adhering to a certain manner of dress, behavior and walking when on the street.

\section{She should also respect herself with her dignity, and that with her dress, how she acts, her behavior. That she's walking in a good way on the street.}

- Young woman, age 28, married, secondary education

The common view among young people in SYPE that women may deserve to be harassed can be explained in part by the tension between condemning harassment as a product of frustration among young men and blaming harassment on the conduct of young women that was apparent in the qualitative respondents' discussions. Even though young people in informal areas were the most likely to reject harassment, and the majority saw what happened to Suha as wrong, it was in young people's understandings of responsibility for harassment that this tension came out. Although data show that harassment is very common in Cairo, many respondents held to the idea that something in Suha's behavior must have caused her to be singled out for harassment. This suggests that harassment is understood, in one respect, as a form of policing women's dress and conduct in public. At the same time, the respondents' focus on the characteristics of the individuals in the scenario - whether the man's potential inebriation or bachelorhood or Suha's clothing - reflected an understanding of harassment as a product of personal morality rather than the broader structure of gender relations in the society. 


\section{Gender equality in the household}

In the domain of gender equality inside the household, we focus on two topics. First, we analyze young people's views on domestic violence and their opinions on what should be done in cases where women are suffering from domestic violence. Then we turn to a discussion of decisionmaking and authority in the household, and particularly between spouses. In this section we draw from an index of questions in SYPE, as well as responses to several of the qualitative vignettes.

\subsection{Views on domestic violence}

Women in Egypt, as everywhere in the world, are exposed to intimate partner violence, which has well-recognized negative health impacts, and constitute a violation of women's human rights (World Health Organization 2013). Egypt's constitution declares that the state is committed to protecting women from any form of violence, and prohibits discrimination based on a variety of factors including sex. The law also specifies punishment for violence committed against another person, including a wife, although there is no clause specific to domestic violence. Nevertheless, the most recent Egypt Demographic and Health Survey found that $30 \%$ of respondents (married women aged 15 - 49) had experienced spousal violence; $25 \%$ had experienced physical violence, $4 \%$ sexual violence and $19 \%$ emotional violence. More than a third of women said that they were sometimes afraid of their spouse, and $36 \%$ said that their spouse insisted on knowing where they were at all times. Nearly three-quarters said that their husbands were jealous or angry if they spoke to another man (Ministry of Health and Population, El-Zanaty and Associates, and ICF International 2015).
Data from the SYPE indicate that, while young people became less accepting of domestic violence between 2009 and 2014, the majority still think that wife beating is justified in some circumstances. SYPE respondents were asked whether a man is justified in beating his wife in six different situations (Appendix 1). In 2009, 11\% of young men and 26\% of young women said that wife beating was not justified in any of the six situations presented. In 2014 , this has risen to $21 \%$ of young men and $30 \%$ of young women. Still, that over two-thirds of young people say that wife beating is justified in at least one of the situations shows substantial tolerance for domestic violence.

In both years, by far the most common situation in which young people thought a man was justified in beating his wife was if she talked to another man, which in the original Arabic also carries some connotation that she has a relationship with the man. Across all situations in both years, young men were more likely to say that domestic violence was justified than young women (Figure 4). Young people in informal areas showed the largest decline in acceptance of domestic violence between 2009 and 2014, as compared to those in urban and rural areas. For example, whereas in 2009, 25.6\% of young people in informal areas said that a man is justified in beating his wife if she argues with him, in 2014 this had declined to $11.8 \%$. The comparable change in urban areas was $28.2 \%$ to $21.0 \%$, and in rural areas $21.7 \%$ to $21.5 \%$. 
FIGURE 4: Percentage of young people who say that it is justified for a man to beat his wife under different circumstances, 2009 and 2014

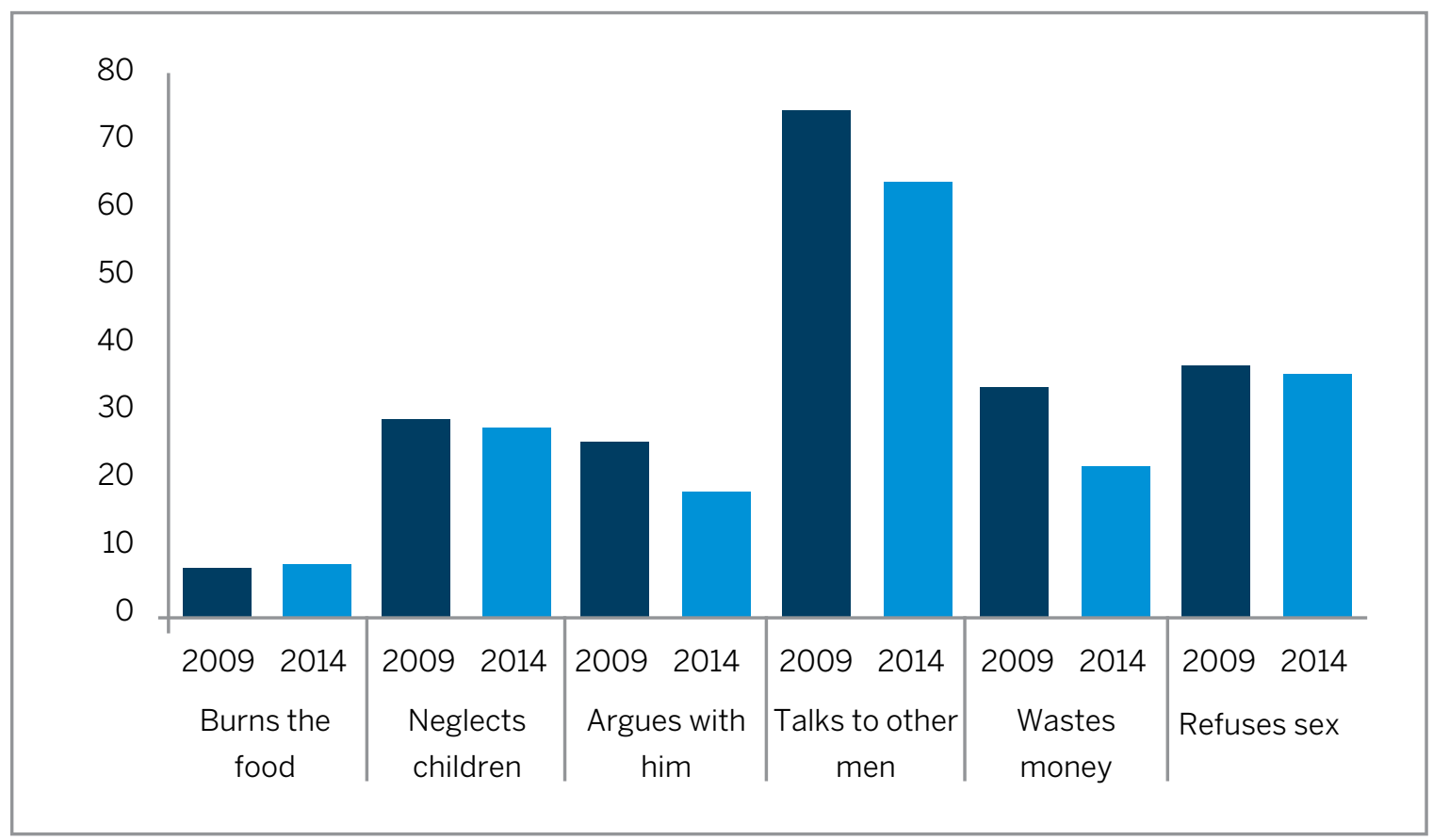

Young people who responded to the qualitative vignette about Hoda, who is regularly subjected to domestic violence by her husband Kareem (Appendix 2), were also less approving of domestic violence than the overall SYPE sample, particularly among the women respondents. When presented with the scenario, the large majority of respondents of both genders said that Kareem was not justified in beating his wife, although a few young men in particular said that it was within Kareem's right or that it depended on what Hoda did. There were not enough married men in the sample to examine variation in men's views on domestic violence by marital status, but young women were equally likely to say that Kareem was not justified in beating Hoda across differences in marital status.

Yet the qualitative respondents' discussion of situations in which men are justified in beating their wives in general did not quite agree with their rejection of domestic violence in Hoda's specific case. Whereas about half of the women stuck with their opinion and said that men are not justified in beating their wives under any circumstances, very few of the young men said this. As with the SYPE sample, the most common reason given for why a man might beat his wife was if she had a relationship with another man. Not listening to the husband, doing something without his permission, or treating him badly were other common reasons given for why a man might be justified in beating his wife. Along with the men, women who were married or had previously been married were more likely to mention such scenarios in which a man would be justified in beating his wife, compared to never married women who were more likely to stick with their rejection of domestic violence regardless of the circumstances.

The qualitative data also suggest that young people have differing opinions about what should be done in situations of domestic violence. There was a general lack of support for legal recourse or other intervention from outside the family in situations of domestic violence. Several young women particularly among those who were not married - did say that Hoda should ask for a divorce, leave Kareem or file a police report. 
The first thing she should do is ask for a divorce, because it's impossible that she will be able to live with someone like that who does not respect her.

- Young woman, age 20, never married, university education

However, no young men suggested that Hoda take any of these measures. In contrast, several young men said that Hoda should just do what her husband wanted in order to avoid beatings, which was only suggested by one of the young women.

\section{She should do what will avoid her husband's anger, see what will make him comfortable and do that. The husband sees things differently than the wife, if he tells her something she should do it so that she can live a good life.}

- Young man, age 23, engaged, secondary education

The only potential recourse in Hoda's situation that young people of both genders suggested fairly commonly was that she complain to her family and have them intervene, sometimes specifically suggesting that she should involve her male relatives or elders in the family.

Someone from her family should stop him, or should speak to the elders in his family.

- Young woman, age 27, married, secondary education

She should separate from him. She should tell her family and his family, so that they meet together. [So] they reduce the beating, or stop it all together. And if there's any problem she should tell her family so they find a solution.

- Young woman, age 29, married, secondary education
At the same time, both young men and women were split on whether Hoda should have told her mother about the beatings when asked. Some respondents said that she should involve her mother, either in support of the idea of family intervention, or because they said the mother would help her to decide what to do (i.e. changing her conduct if she was in the wrong, or intervening with the husband).

\section{She should tell her family...even if she is wrong she should tell them that one, two, three happened, the right and the wrong she should tell them, and they will decide [between right and wrong] and at the same time they will get her rights for her, that he can't beat her. \\ - Young man, age 30, never married, preparatory education or less}

Yet many others said that Hoda was right not to tell her mother, and that she was right to protect the secrets of her home. These respondents argued that the mother would surely intervene and exacerbate the problem, potentially even leading to divorce.

\section{Yes she was very right [not to tell her mother], the best thing is that she keeps the secrets of the home. \\ - Young man, age 21, never married, preparatory education or less}

Respondents of both genders were also unsure about the legal situation surrounding domestic violence in Egypt. Just under half said there was no law prohibiting a man from beating his wife, and somewhat smaller groups said there was a law, or that they did not know. When asked if they thought there should be a law against wife beating, nearly all of the women said yes, whereas the men were split on whether such a law should exist. Whereas young people who supported the idea of a law said that this would protect women and help them to 
take their rights, the young men who opposed a law against domestic violence objected to the idea of legal interference with their understanding of men's positions as heads of household.

It can't be [that there is a law], no one [male] will accept that someone will come into his house and say 'you hit your wife.' She's my wife, it's none of your business. It's my house and I'm free in it. But there are things one can't do, not beating day and night....

- Young man, age 26, married, technical post - secondary education

This was in accordance with views of the majority of respondents that issues of domestic violence should be kept within the family, at most to be solved by negotiation between the two spouses' families rather than outsiders. In this view, women suffering from domestic violence should seek the protection of their families rather than the legal system. Resistance to the idea of legal intervention into family matters was also expressed in some of the other domains covered in Section 5, and puts women at a substantial disadvantage in terms of being able to claim any legal protections that are available to them. Fundamentally, respondents' views on domestic violence and how it should be solved were based on an understanding of male household authority, which we discuss in more detail in the following section.

\subsection{Household decision-making and authority}

Turning to gender roles within the household more generally, the SYPE data demonstrate that young people continue to hold conservative views, and specifically high levels of support for the idea that men should hold authority over their female relatives. In $2014,62 \%$ of young people (67\% of men and $57 \%$ of women) agreed that a girl should obey her brother even if he is younger, $48 \%$ ( $56 \%$ of men and $39 \%$ of women) agreed that the husband alone should make decisions about how to spend money, and $77 \%$ (79\% of men and $75 \%$ of women) agreed that a woman should obtain her husband's permission before doing anything.

FIGURE 5: Young people's attitudes towards authority and decision-making in the household, by residency, 2014

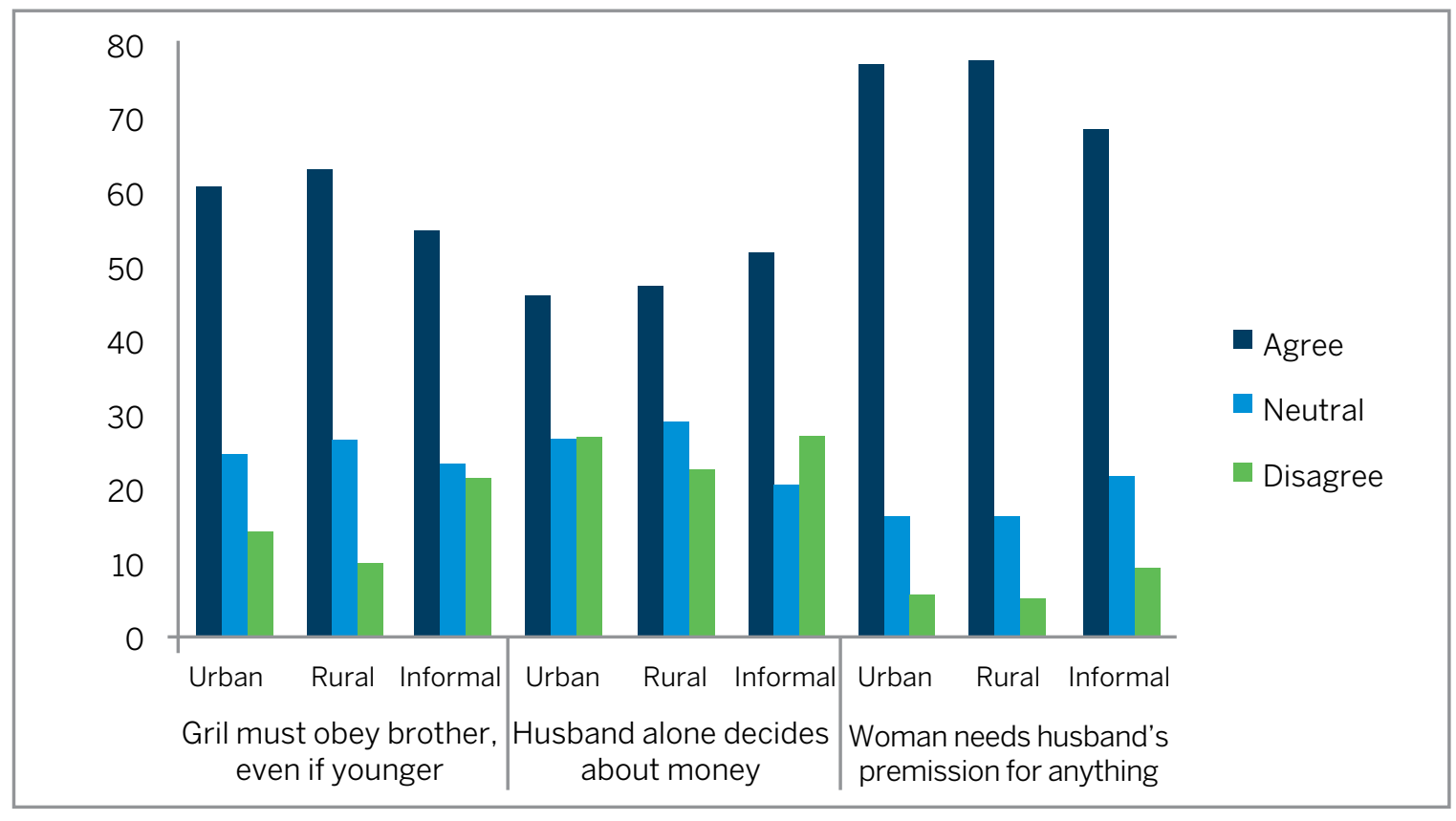


As shown in Figure 5, young people in informal areas held somewhat more egalitarian attitudes towards authority in the household than their urban and rural peers, except when it came to decisionmaking about money. Still, nearly $70 \%$ of young people in informal areas supported the idea that women should obtain their husbands' permission in order to do anything.

Similar views regarding household authority were expressed by respondents in the qualitative sample, whose discussions of issues such as girls' education, domestic violence and divorce were premised on a strongly gendered expectation of roles within the household according to the male breadwinner-female homemaker model discussed above. This understanding was summarized succinctly by one young man who, in responding to the vignette about Laila, said that the girl should leave school and marry:

\section{Girls' education isn't important because in the end she will marry and stay home, and cook, clean and wash. Of course education won't benefit her in anything, what she will need is her husband. \\ - Young man, age 18, engaged, secondary education}

While many other respondents disagreed with this young man regarding the importance of girls' education, the expectation that women will prioritize home and husband was the basis for many of their reactions to the vignettes. For example, girls' education was often described by respondents as a general social good and something that would benefit her family, rather than an investment in her own future or employability.

\section{When she gets married how will she raise her children if she is not educated?}

- Young woman, age 19, never married, university education

\section{The boy will benefit from the education but either way the girl will marry and her husband will take care of her. Work depends on boys so he'll benefit from the education. \\ - Young man, age missing, never married, secondary education}

In addition to devaluing the possibility of women's work outside the home, which we discussed in Section 3.2, these reactions speak to the strength of young people's expectations of gendered family roles.

Young people's discussions of domestic violence also reveal the extent to which their expectations of a male breadwinner-female homemaker household model also entailed husbands' authority over their wives. Many of the situations in which the qualitative respondents said a man would be justified in beating his wife had to do with the wife disobeying her husband's authority. Along these lines, a number of respondents suggested courses of actions for Hoda that involved identifying and remedying what she did to anger her husband and cause the beating, as opposed to addressing the husband's violence directly. Other respondents cautioned that escalation of the problem to family could lead to further problems and even divorce, at times implying that Hoda was better off living with abuse than risking the breakup of her family.

\section{Of course [she was right not to tell]. Her mother will make the issue bigger and it might end in divorce. - Young woman, age 26, married, preparatory education or less}

As we discuss in Section 5.1 below, a similar focus on a woman's need to be in a marriage - and the social consequences of marital breakup - ran through some of the respondents' discussions of divorce. 
The initial section of the vignette on divorce, in which respondents were asked about the scenario of a couple, Hatem and Hanan, who have two daughters (Appendix 2) was the most direct discussion of household decision-making in the qualitative study. In the scenario, Hatem wants to have another child in the hopes of having a son but Hanan does not want a third child. Respondents were quite split with regards to who was in the right in this scenario, with young women leaning more towards the wife's views and young men's towards the husband's. Both young men and women who said that Hanan was right not to have a third child cited the importance of being able to bring up their two children well, both financially and in terms of parents' attention and ideal family size, as well as the fact that the couple could not be certain that a third child would be a boy. Several young women also said that it should make no difference whether their children were boys or girls.

Among those who said that Hanan was wrong to not want a third child, however, considerations of the gender mix of the children (in that boys would support their parents in the future) and how many children the family could afford were accompanied by the view among some respondents that Hanan should follow her husband's wishes. Young men were particularly likely to say that Hanan had to do what her husband wanted, whereas a few young women said that she should give in so as to avoid causing problems between the couple. Both groups pointed out that the husband might marry a second wife if Hanan did not agree to have a third child.

\section{You [female] are refusing what I}

want, I will turn to another one...even against my wishes, if I see another

woman I like I'll marry her so that she gives me the children I want.

- Young man, age 26, married, technical post - secondary education
[Refusing] threatens her family, it'll be easier for him, if he doesn't divorce her, to marry another one because she isn't willing to do what he wants.

- Young woman, age 20, engaged, technical post - secondary education

These views corresponded with the gender differences in young people's views of who in the couple should make decisions about family planning. Whereas about half of both young men and women said that the couple should decide about family planning together, the other half of the young men nearly all said that the man should decide. The other young women were split between those who said the man should make family planning decisions and those who said the woman. The majority of respondents of both genders who said that men should make decisions about family planning focused on the husband's role as the household breadwinner, saying that this meant he was best able to judge how many children he could support and therefore should make the decision about how many to have.

The man, why? Because he's the one who is responsible for the family...he's the head of household, so he's responsible for taking that decision, he's the one who works, he's the one who provides for he household, he's the one who raises the children.

- Young woman, age 25, married, technical post - secondary education 
He is the one who knows the

[household] situation, his work, his

income...the man is the provider

of the household, he's the one who

makes decisions.

- Young man, age 19, never married, secondary education

A few of the men respondents, however, simply said that the husband should make decisions about family planning because he was the head of the household and its authority.

The man of course. He's the one who makes decisions and the woman is the one who sees to what he wants, and that's it.

- Young man, age 26, never married, preparatory education or less

In contrast, the women and few men respondents who said that the wife should be primarily responsible for decisions about family planning explained this in terms of her role as the primary caretaker of the children, and thus the one who would be burdened more by a third child.
She is the one who gets pregnant... The woman is the one who cooks and cleans and does everything, she's the one who takes care of them, so she is the one [who decides].

- Young woman, age 23, divorced, preparatory education or less

Together, these responses suggest broad acceptance of a model of gender relations in which women are to a great extent defined by their marriages, and are expected to defer to their husbands. Only two respondents brought up Hanan's employment in their discussions of the couple's childbearing decisions; rather, the focus was on her role as a wife and mother, and (along with household finances) the consequences of disagreeing with her husband on something so fundamental. Similarly, respondents' discussions of education and work were based on the prioritization of girls' future roles as wives and mothers versus men's roles as breadwinners, and of domestic violence on the understanding of the authority of a male household head. 


\section{Personal status law and legal equality}

Finally, in the domain of legal equality we examine two issues: divorce and inheritance. In addition to women's right to a divorce, in the first section we examine the situations in which young people thought men and women were justified in asking for a divorce. In discussing inheritance, we focus on the issue of families encouraging women to give up inheritances that they are legally entitled to.

\subsection{Women's right to a divorce}

The legal system governing women's rights in marriage and divorce in Egypt is known as personal status law. Personal status law is based on an individual's religion, and thus is different for Christians and Muslims. For the majority Muslim population, and with reference to Islamic jurisprudence, personal status law in modern Egypt allows a woman to file for divorce only when she can prove certain types of harm, such as abandonment, whereas men do not face such restrictions and can unilaterally divorce their wives for any reason (Bernard-Maugiron and Dupret 2008). One situation in which harm is considered inflicted is when the husband marries another woman without the knowledge and consent of his first wife, ${ }^{2}$ the scenario referred to in the vignette posed to qualitative respondents, in which case the wife may file for divorce.

In 2000, Egypt implemented a reform to the personal status law allowing for khul' divorce, which allows for a woman to unilaterally initiate a no-fault divorce from her husband provided that she renounces her financial rights upon divorce (Bernard-Maugiron and Dupret 2008; Al-Sharmani 2009; Sonneveld 2010). In 2004, Egypt also established family courts, which were meant to streamline family law cases, and which introduced mandatory mediation into divorce proceedings (AlSharmani 2009). Yet in practice, women in Egypt face numerous challenges in obtaining their rights to divorce, as well as their finaninal rights after divorce. These challenges have been documented to include the inadequacy of human and physical resources for the mediation process, the length and cost of the legal proceedings, judges' and other court staff's prejudicial treatment of women (e.g. trying to convince them to abandon their divorce claim, rulings on financial matters) and husbands' refusal to cooperate with court proceedings or pay spousal support post-divorce (Bernard-Maugiron and Dupret 2008; Al-Sharmani 2009; Sonneveld 2010). Women's right to a divorce is thus an area in which conservative attitudes are a barrier to gender equality in the legal system, despite the recent enactment of laws intended to improve women's status.

Data from SYPE indicate that young people became more accepting of women's right to file for a divorce between 2009 and 2014, which may reflect gradual adjustment to the changes in personal status law implemented in the early 2000s. Young women were considerably more egalitarian on this issue in both years; by 2014 , $64.7 \%$ of young men and $81.8 \%$ of young women said that a woman has the right to ask for a divorce.

2 Law 25 of 1929, as amended by law 100 of 1985 
FIGURE 6: Percentage of youth who think that women have the right to ask for a divorce, 2009 and 2014, by gender

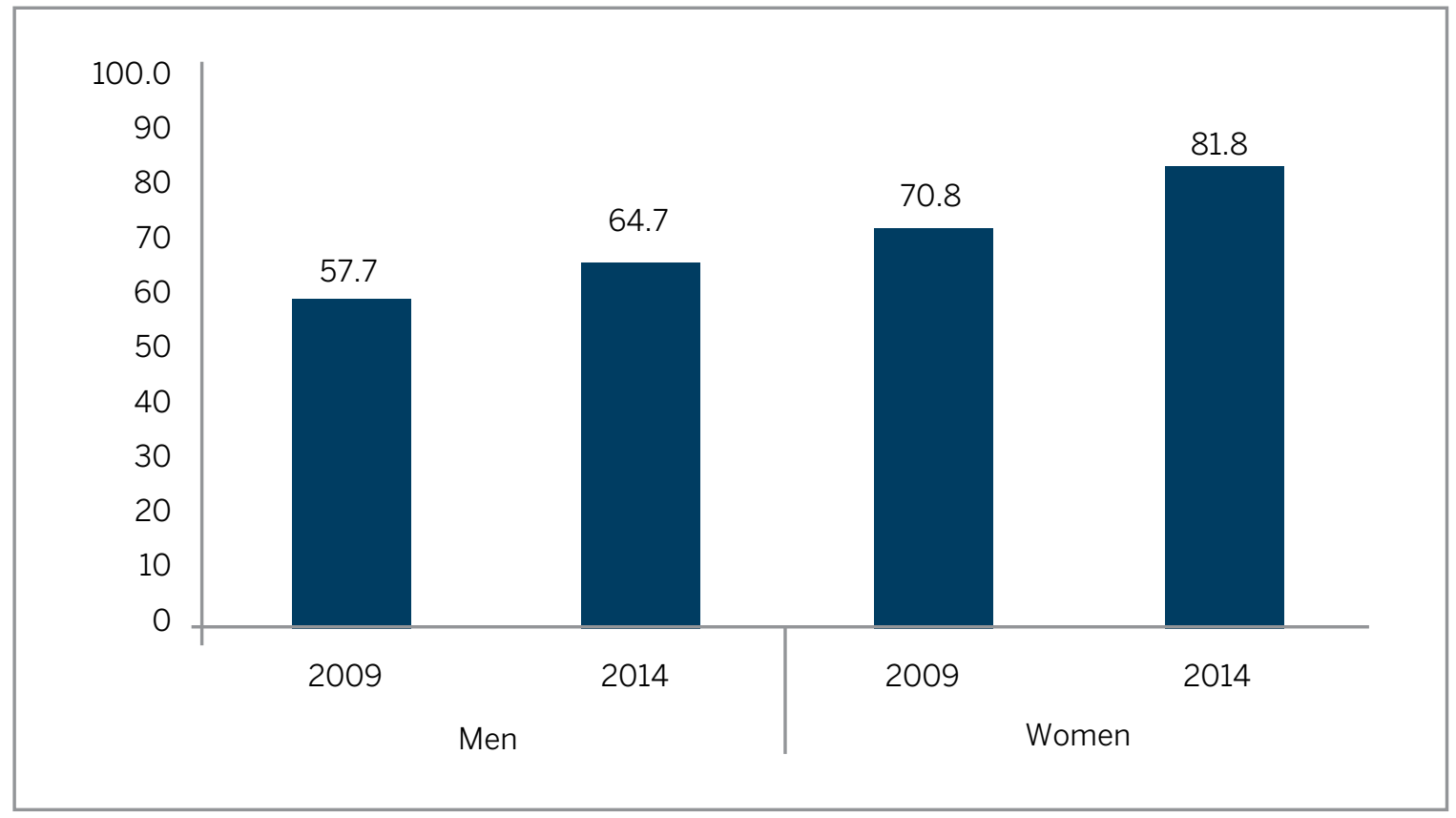

Among those young people who said that women have the right to ask for a divorce, views on the situations in which she is justified in asking for a divorce also changed somewhat between 2009 and 2014, particularly among young men. Of the eleven situations in which young people were asked whether a woman has the right to ask for a divorce (Appendix 1), the most common situations in which they agreed were if she hates her husband (86\% in 2009 and $78 \%$ in 2014), if her husband marries another woman (70\% in 2009 and $75 \%$ in 2014), if her spouse beats her regularly (75\% in 2009 and $71 \%$ in 2014), and if her spouse is in a relationship with another woman (75\% in 2009 and $68 \%$ in 2014). Young people were least likely to say that a woman has the right to ask for a divorce if her spouse does not take her opinion into consideration (36\% in 2009 and $30 \%$ in 2014) or if her spouse beats her once (21\% in both years).

Respondents in the qualitative study were posed a scenario corresponding with one of the situations under which SYPE respondents were most likely to think a woman is justified in asking for a divorce
- when her husband marries another woman. In the continuation of the scenario discussed in the previous section, Hatem decides to marry another woman without telling Hanan, under which circumstances the majority of both men and women respondents said that Hanan had the right to file for a divorce, as she did in the scenario. The qualitative respondents viewed Hatem's actions as form of infidelity, saying that he should have discussed the second marriage with Hanan before proceeding.

\section{It's her right, why? Now, you talked to me, ok, and I told you we don't have to have another child. And like this, you went and married another one, that's called infidelity. And you went and got married behind my back without me knowing. \\ - Young woman, age 28, married, secondary education}


I think it's her right, and something else, he ruined his family with what he did there. In shari'a it's your right that you marry four but tell her that you're going to marry, and if she doesn't agree get divorced then that's it. That way I protect my family and my children.

- Young man, age 18, never married, secondary education

Despite the agreement of the majority of the respondents with Hanan's right to divorce in this case, there was also a minority of young people who said that she was not within her rights to file for divorce. Although those in disagreement were mixed in gender, men's and women's reasons for why Hanan should not file for divorce differed. The male respondents who disagreed with Hanan's right to divorce emphasized that Islam grants men the right to marry multiple wives, whereas the women argued that Hanan should not file for divorce in order to preserve her family and her children.

In the Islamic religion, four wives are allowed, but he was wrong because he should have sat with her and talked to her, 'do what I want' and try to get her to agree with him, since either way he is going to marry.

- Young man, age 21, never married, secondary education

No, no it's not her right to ask for a divorce. It's not an issue of it's her right and all that, but she shouldn't ask for a divorce so that she protects her daughters...she could involve her family and his family, for sure her family won't agree with the situation.

- Young woman, age 25, never married, university education
Men and women respondents also differed as to the problems that Hanan would face during the court procedure for obtaining a divorce. Most of the young women said that Hanan would suffer from several challenges in trying to obtain a divorce, such as slow legal proceedings, financial problems including the cost of lawyers, and problems caused by the husband himself, including threats of taking the children or preventing her from exercising her right to divorce.

There's a lot of costs and hassle because it [divorce] doesn't happen easily. The courts are full of cases, so it'll be postponed years and years, so she'll have to spend on her children during those years. She'll be exhausted coming and going to the consultations, and the bribes, the lawyers, the costs and all that.

- Young woman, age 28, married, secondary education

He won't divorce her easily, he'll try to create conflict with her, and he'll take her children from her and prevent her from seeing them.

- Young woman, age 28, married, secondary education

Although some young men also mentioned such problems with the court proceedings or husband, the majority said that the biggest problem Hanan would face would be the social response, and being blamed for having taken the decision to divorce, whether by the family, the community or at her work.

The elders, like her mother for example, will tell her 'my daughter, don't ruin yourself, stay in your home, it doesn't matter if he married another one, for the sake of your children.'

- Young man, age 18, never married, secondary education 
Similarly, both young men and women agreed that the society's negative view of divorced women would be the main challenge facing Hanan after obtaining a divorce. Respondents said that their communities would view a divorced woman as unable to raise her children and take care of the home. A number of respondents also said that she would find it very difficult to raise her children without a father at home, and that her children might be negatively affected by having a split family. Others said that Hanan would be subject to greater scrutiny of her movements and actions given that she did not have a man at home.

There will be problems in everything, like when she goes out, when she comes home, like that. And of course talk here and there, 'you're divorced,' even from her mother and father, 'don't go out, because you're a divorced woman and people will talk'..

- Young man, age 30, never married, preparatory education or less

\section{When a man is in the house there is a foundation of the home. If you think of yourself living alone, you are responsible for two children, how will you feed them? How will you clothe them, take them to school? And that's apart from the security. \\ - Young woman, age 26, married, preparatory education or less}

Thus, while young people appear to be becoming more accepting of women's right to divorce in Egypt in general, their opinions vary regarding when she is justified in doing so. Greater acceptance of women's right to divorce in the abstract also does not necessarily translate into greater acceptance of divorced women, as respondents noted the continued social disapproval of divorced women and the numerous challenges that this would pose in both divorce proceedings and a divorcee's daily life. The negative view of divorced women was also related to the prevailing model of household gender relations, in which men were seen as the household head and authority, as well as its provider. The absence of this figure in the household, along with the general view that marriage is very important for women, led to the expectation that divorced women would face a variety of practical and reputational challenges.

\subsection{Women's right to inheritance}

A prevailing environment of gender inequality also disadvantages women in other legal domains, as can be seen in the case of inheritance. In accordance with Islamic law (shari'a), Egyptian law grants women the right to inherit. Despite this, customs and traditions in rural parts of Egypt in particular often prevent women from exercising their right to their inheritance, as women may be pressured to give up the property to which they are entitled in favor of their male relatives. As with divorce, there are formidable legal procedures that women who are denied their inheritance must face in order to challenge such practices. In order to combat this problem, in early 2016 , official newspapers published notice of an amendment to Law 77 of 1943 regarding inheritance. The amendment specifies a prison sentence and fine for anyone found guilty of preventing another party from receiving the share of inheritance that party is due according to the law.

Although the law is an important step forward, change in attitudes and social norms play an important role in making sure that women's inheritance rights are protected. Young people in SYPE were asked to respond to the statement "even though shari'a grants girls/women the right to inheritance, in some cases girls should not get their share so as to keep the money or land in the family." Young people showed considerable 
support for women's right to inheritance, with $75.8 \%$ of young men and $79.5 \%$ of young women in 2014 disagreeing with the statement. This was also the smallest gender gap in young people's attitudes demonstrated in any of the domains, in that young men were nearly as supportive of women's inheritance rights as were young women themselves. Young people in informal areas were most likely to disagree with women giving up their inheritance rights (85.5\%), compared to those in urban (76.3\%) and rural (77.0\%) areas.

The qualitative respondents were asked about the issue of women's inheritance through a very similar scenario of a woman whose brothers want to prevent her from taking her share of the inheritance after the death of their father (Appendix 2). Fearing that the sister's share of the family land will eventually pass to her husband, the brothers offer her money but want her to sign away her right to the land. The majority of respondents, both men and women, rejected the position of the brothers in the story, emphasizing that this was against the provision in Islamic law that provides for women's inheritance.

Of course it's wrong, whether it [the land] goes to her husband or not, this is God's law, and what is in the law is that each one takes his right. It's not alright that I take your right, it's on me to give you your legal right.

- Young man, age 26, never married, university education

However, although the majority of respondents knew that both the law and shari'a grant women the right to inheritance, they were unsure of the details of what exactly those rights were.

The inheritance should be distributed among the three of them [the boys] like they are distributing, for example the boy two-thirds and

the girl a third, or something like that.

- Young woman, age 18, engaged, secondary education

At the same time, some respondents said that the uneven distribution of inheritance between boys and girls, as well as the sister's potential interest in relinquishing her inheritance rights, was based on the fact that women have a male provider (potentially including the brothers), whereas men would themselves be heads of households.

When asked what the sister in the scenario should do in response to her brother's actions, the majority of young people said that she should pursue her inheritance rights through legal means by filing a report that her brothers refused to give her the inheritance.

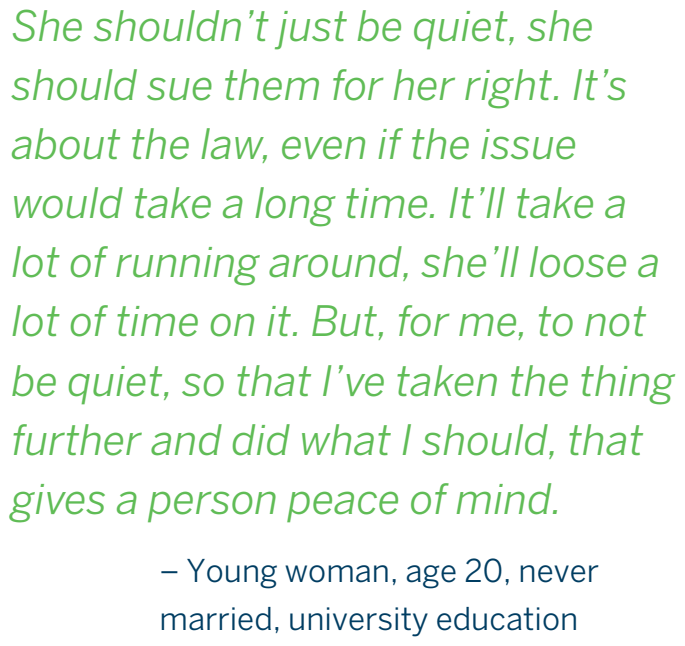

In contrast, some respondents, again both men and women, were strongly discouraging of the idea of resorting to legal measures to deal with this inheritance question. They recommended instead that the sister turn to one of the elders of the family (el kubar) in order to reach an agreement with her brothers about the issue, and that if no agreement could be reached, she should submit to the brothers' wishes. 
Bring in their uncles, any elders in

the family. If they [the brothers] still

refuse, then that's it, so that she

doesn't lose her brothers in order to

take her legal rights.

- Young man, age 26, married,

technical post - secondary education

Young people's awareness of the legal situation around the denial of women's inheritance rights was the main area where gender differences were seen in response to this scenario. Whereas the majority of young women said that no law criminalizing the denial of inheritance rights existed, the majority of young men stated that such a law did exist.

\author{
Unfortunately there isn't [such a \\ law], even if it exists on paper we \\ have never heard that someone took \\ another's right and that one went to \\ the law. There's nothing like that at \\ all. \\ - Young woman, age 25, never \\ married, university education
}

Denying someone their inheritance is denying their rights, so for sure there is a legal clause penalizing that someone is denied their right, and punishing that.

- Young man, age 25, engaged, university education

It was unclear, however, how specifically even those young people who said there was a law knew about the recent legal change penalizing denial of inheritance rights. Overall, young people's uncertainty about the legal situation around women's inheritance rights suggests the need for greater publicity around the law, as well as general education about those rights. We discuss the issue of legal change versus change in social norms around gender equality in greater detail in the conclusions in the following section. 


\section{Conclusions and policy recommendations}

Our findings agree with those of other studies demonstrating conservative gender role attitudes among Egyptian young people (Mensch et al. 2003; Population Council 2010; Salemi and Rashed 2015). Data from SYPE indicate that young people in Egypt's growing informal urban areas, or 'ashwaiyyat, generally hold more egalitarian gender views than their peers in urban or rural areas. Nevertheless, a companion qualitative study conducted only in informal areas shows that, even if young people in these areas are the most egalitarian overall, they still support separate spheres and roles for men and women across many domains of public and private life.

The basis of young people's conservative attitudes regarding gender roles and women's rights was their adherence to a traditional household model in which men are seen as the household head, its breadwinner and main authority, whereas women are expected to be housewives and to focus on their husbands and children. This expectation was exemplified in a phrase many respondents used when speaking about girls: "her future is marriage" (maseerha el gawaz). This model of household relations shaped gender roles in both the public and private spheres, and for men - who were expected to fulfill this breadwinner role - as well as women. That both young men and women generally adhered to this model helps to explain why women often held conservative gender role attitudes that may seem to lead them to support positions (e.g. approval of domestic violence) that are against their own interests. However, it is important to note that both the SYPE and qualitative data indicate that young women held more egalitarian attitudes than young men, which is an important trend to monitor in these cohorts as they age.

In the public sphere, this positioning of marriage as the key element in a girl's future influenced young people's understanding of the importance of a girl's education, which was often seen in terms of its positive influence on her marriage and family outcomes. Even though a number of young people also said that education would help a girl to get a good job, overall women's employment was not prioritized and was spoken about as a secondary or temporary undertaking that would most likely be given up when she married. For men, in contrast, education was described as a foundation for their future role as the household breadwinner, and there was a strong expectation among young people of both genders that men would be the provider of a household. This expectation also contributed to conservative attitudes regarding women's employment and the view that men's employment is more important than women's.

The male breadwinner-female homemaker model was associated with young people's expectation of men's authority within the household. Young people in both SYPE and the qualitative study demonstrated support for men's authority over their spouses across a range of daily activities and more major decisions. Although there was also support for joint decision-making for particularly important issues such as having another child, men's expected role as household head and provider was tied, in young peoples' views, to the role of key decision-maker. Some young people explained this in terms of men's greater contact with the society outside the household and their role as breadwinner, which was seen as putting them in a better position to have the information to make major decisions. Others, in contrast, and particularly some young men, said that men had the right to be the authority within the household simply because they were men.

A particularly concerning aspect of young people's expectation of male authority in the home was that at times this was used to justify actions that had negative consequences for their spouses. Young people demonstrated less acceptance of domestic 
violence in 2014 than they did in 2009, which is an encouraging trend. Nevertheless, the majority of young people said that domestic violence would be justified in at least some situations, and many of their discussions of such situations were related to women disobeying their husband's authority. A woman refusing to accept her husband's will on a major decision - such as that to have another child - was also seen as a likely reason for divorce by some young people. In contrast, a woman filing for divorce from her husband, even if he took another wife, was seen as something to be considered carefully and relatively few young people said that a woman was justified in asking for a divorce because her husband did not take her opinion into consideration.

Finally, the idea that women should be subject to authority at home contributed to the discourse around women deserving sexual harassment; that women in public spaces may not be conforming to 'correct' modes of behavior (in terms of dress, speech, walk etc.) enforced by the family was often used to explain why they were harassed. Although many other factors certainly contribute to the prevalence of sexual harassment in Egypt (Egyptian Center for Women's Rights 2008; Harassmap 2014), our findings suggest that at least one dynamic behind this phenomenon in Egypt is that of public policing of women's behavior when this is seen not to conform with expected gender roles.

Our findings also highlight the extent to which conservative attitudes based in this model of gender relations may influence practices even in the face of legal change. Several positive legal steps have been taken in Egypt over the past years to combat practices that negatively affect women's outcomes, including the law against sexual harassment, allowing khul' divorce, and the law to protect women's inheritance that are discussed in this report. However, the efficacy of the first two legal measures has been critiqued, and it is still too early to tell whether the amendment to the inheritance law will have an impact. Enforcement of the laws is certainly an important issue that is beyond the scope of this report, but our findings also suggest that legal changes may have limited effect when the society's attitudes still strongly support gender-unequal practices.

The persistence of conservative gender attitudes has important implications for each of the areas we discuss in which legal intervention already exists in Egypt or is common in other contexts, although in different ways. In the case of sexual harassment, although a law exists, young people's views on the issue demonstrate a tendency to blame the victim, which may explain in part why harassment is so massively underreported, and why few legal cases may be pursued. Until attitudes toward harassment change dramatically, and harassment comes to be viewed as unacceptable regardless of the characteristics or behavior of the victim, this is unlikely to change. In the case of divorce, SYPE demonstrates that acceptance of women's right to divorce has increased notably among young people, which is a positive development. Nevertheless, young people also noted that the society has a negative view of divorced women, and some were discouraging of divorce as a potential response to the situations faced by women in several of the scenarios. In short, agreeing with a woman's right to divorce is not the same as accepting divorced women. Such conservative attitudes have been noted to influence the proceedings of family courts, including whether or not women get the services and benefits to which they are entitled (Bernard-Maugiron and Dupret 2008; Al-Sharmani 2009; Sonneveld 2010), and the signals from our findings are mixed as to whether or not this is likely to change among younger generations.

Many young people also suggested that marital problems were better solved through extended family negotiation rather than outside intervention, in the case of divorce as well as domestic violence. Young people were unsure of the legal situation around domestic violence, and support for the idea of a law specifically targeted to domestic violence was mixed. These findings suggest that any law against domestic violence would face substantial opposition and be difficult to enforce. Finally, young people's attitudes regarding women's rights to inheritance may have the most positive indications for the recently passed amendment protecting 
inheritance rights. Based on its foundation in Islamic law, young people were quite supportive of women's right to inheritance. Although some were also against bringing this type of family issue to court, there was broader support for legal intervention in the area of inheritance than the other domains we discussed.

The low awareness among our study respondents of the new inheritance amendment, its contents, and the Islamic law to which it refers, however, highlights the need for such legal changes to be accompanied by broad public information campaigns that aim to inform people of the purpose of the law. These campaigns should work through a variety of media, including local sources such as community leaders, religious institutions and Community-Based Organizations in order to reach young people through sources that they trust. Gender role attitudes are a deeply held component of individuals' beliefs, and sustained, interactive engagement with young people is likely needed in order to influence them. Along with public information campaigns, strengthening enforcement of existing laws such as the law against sexual harassment is critical. In order to achieve this, programs to address the gender biases of law enforcement officers and other actors in the legal system are likely also needed.

More broadly speaking, education was one of the factors that was most consistently associated with more egalitarian gender role attitudes in SYPE (Salemi and Rashed 2015), and girls' education was one of the aspects of women's rights that young people showed the most support for. The association between education and attitudes was particularly strong, in some areas, among young women themselves. A positive outcome of education, and particularly girls' education, may thus be its influence on gender role attitudes, which should in turn lead to greater support for education. However, if education is to serve as a basis for support of equality in other domains, a more rights-based understanding of girls' education is important to achieve that goes beyond the current understanding of education as a means to certain socioeconomic outcomes. Ministry of Education policy as well as curricula should support such an approach to girls' education, as well as NGO and advocacy programs.

Critically, efforts to support a rights-based approach to girls' education, as well as other efforts to address youth gender roles, must involve men as well as women. Young men hold widely more conservative attitudes than young women, and given the model of male household authority that so many young people in Egypt held to, they have a strong influence over the outcomes of their wives, daughters and sisters. In order to work towards more egalitarian gender role attitudes among Egyptian young people, programs and policies must therefore build from the understanding that these attitudes are not only about women, but rather are a part of the social norms that affect women and men's outcomes alike. 


\section{References}

Al-Sharmani, Mulki. 2009. "Egyptian

Family Courts: A Pathway of Women's

Empowerment?" Hawwa 7 (2): 89-110.

Assaad, Ragui. 2007. "Institutions, Household Decisions, and Economic Growth in Egypt." In Explaining Growth in the Middle East, edited by Jeffrey Nugent and M. Hashem Pesaran, 385411. Amsterdam: Elsevier.

Assaad, Ragui, and Fatma El Hamidi. 2009. "Women in the Egyptian Labor Market: An Analysis of Developments, 1988-2006." In The Egyptian Labor Market Revisited, edited by Ragui Assaad, 117-56. Cairo: American University in Cairo Press.

Assaad, Ragui, and Caroline Krafft. 2015. "Is Free Basic Education in Egypt a Reality or a Myth?" International Journal of Educational Development 45: 16-30.

Atkinson, Maxine P., Theodore N. Greenstein, and Molly Monahan Lang. 2005. "For Women, Breadwinning Can Be Dangerous: Gendered Resource Theory and Wife Abuse." Journal of Marriage \& Family 67 (5): 1137-48.

Barsoum, Ghada. 2004. The Employment Crisis of Female Graduates in Egypt: An Ethnographic Account. Cairo Papers in Social Science. Cairo: American University in Cairo Press.

Barter, Christine, and Emma Renold. 2000. “'I Wanna Tell You a Story': Exploring the Application of Vignettes in Qualitative Research with Children and Young People." International Journal of Social Research Methodology 3 (4): 307-23.

Bernard-Maugiron, Nathalie, and Baudouin Dupret. 2008. "Breaking Up the Family: Divorce in Egyptian Law and Practice." Hawwa 6 (1): 52-74.
CAPMAS. 2008. "Study of Informal Settlements in Egypt." Cairo: CAPMAS.

Corrigall, Elizabeth A., and Alison M. Konrad. 2007. "Gender Role Attitudes and Careers: A Longitudinal Study." Sex Roles 56 (11-12): $847-55$

Cunningham, Mick, Ann M. Beutel, Jennifer S. Barber, and Arland Thornton. 2005. "Reciprocal Relationships between Attitudes about Gender and Social Contexts during Young Adulthood." Social Science Research 34 (4): 862-92.

Davis, Shannon N., and Theodore N. Greenstein. 2009. "Gender Ideology: Components, Predictors, and Consequences." Annual Review of Sociology 35 (1): 87-105.

Egyptian Center for Women's Rights. 2008. "Clouds in Egypt's Sky, Sexual Harassment: From Verbal Harassment to Rape." Cairo: ECWR.

Fan, Pi-Ling, and Margaret Mooney Marini. 2000. "Influences on Gender-Role Attitudes during the Transition to Adulthood,." Social Science Research 29 (2): 258-83.

Farré, Lídia, and Francis Vella. 2013. “The Intergenerational Transmission of Gender Role Attitudes and Its Implications for Female Labour Force Participation." Economica 80 (318): 219-47.

Fortin, Nicole M. 2005. "Gender Role Attitudes and the Labour-Market Outcomes of Women across OECD Countries." Oxford Review of Economic Policy 21 (3): 416-38.

Harassmap. 2014. "Towards a Safer City - Sexual Harassment in Greater Cairo: Effectiveness of Crowdsourced Data." Cairo: Harassmap. 
Ismail, Sarah, Nahla Abdel-Tawab, and Lila

Sheira. 2015. "Health of Egyptian Youth in 2014: Knowledge, Attitudes and Behaviors." In Panel Survey of Young People in Egypt 2014: Generating Evidence for Policy, Programs and Research, edited by Rania Roushdy and Maia Sieverding. Cairo: Population Council.

Krafft, Caroline. 2015. “Educational Experiences of Youth in Egypt: Who Attends School, Who Succeeds, and Who Struggles." In Panel Survey of Young People in Egypt 2014: Generating Evidence for Policy, Programs and Research, edited by Rania Roushdy and Maia Sieverding. Cairo: Population Council.

Mensch, Barbara, Barbara Ibrahim, Susan Lee, and Omaima El-Gibaly. 2003. "Gender-Role Attitudes among Egyptian Adolescents." Studies in Family Planning 34 (1): 8-18.

Ministry of Health and Population, El-Zanaty and Associates, and ICF International. 2015. "Egypt Demographic and Health Survey 2014." Cairo, Egypt and Rockville, Maryland, USA: Ministry of Health and Population and ICF International.

Population Council. 2010. "Survey of Young People in Egypt." Cairo: Population Council.

Roushdy, Rania, and Irene Selwaness. 2015. “Young People's Labor Market Outcomes during a Period of Transition." In Panel Survey of Young People in Egypt 2014: Generating Evidence for Policy, Programs and Research, edited by Rania Roushdy and Maia Sieverding. Cairo: Population Council.

Roushdy, Rania, and Maia Sieverding, eds. 2015. Panel Survey of Young People in Egypt 2014: Generating Evidence for Policy, Programs and Research. Cairo: Population Council.

Salemi, Colette, and Ali Rashed. 2015. "Continuing Conservatism: Gender Attitudes among Egyptian Youth." In Panel Survey of Young People in Egypt 2014: Generating Evidence for Policy, Programs and Research, edited by Rania Roushdy and Maia Sieverding. Cairo: Population Council.
Schoenberg, Nancy E., and Hege Ravdal. 2000. "Using Vignettes in Awareness and Attitudinal Research." International Journal of Social Research Methodology 3 (1): 63-74.

Sieverding, Maia. 2012. "Gender and Generational Change in Egypt." Ph.D. Diss., Berkeley: University of California Berkeley.

Sonneveld, Nadia. 2010. “Khul' Divorce in Egypt: How Family Courts Are Providing a 'Dialogue' between Husband and Wife." Anthropology of the Middle East 5 (2): 100-120.

UNDP. 2006. “The Arab Human Development Report 2005: Towards the Rise of Women in the Arab World." New York: United Nations Development Programme, Regional Bureau for Arab States.

UNDP and INP. 2010. “Egypt Human Development Report 2010, Youth in Egypt: Building Our Future." Cairo: United Nations Development Programme and Institute of National Planning (Egypt).

World Economic Forum. 2015. "The Global Gender Gap Report 2015." Geneva: World Economic Forum.

World Health Organization. 2013. Global and Regional Estimates of Violence against Women: Prevalence and Health Effects of Intimate Partner Violence and Non-Partner Sexual Violence. Geneva: World Health Organization. http://apps.who.int/iris/handle/10665/85239. 


\section{Appendix 1: SYPE Survey Questions on Gender Role Attitudes}

Table A1: Gender role attitudes measures

\section{Public sphere}

1. Educating boys is more important than educating girls

2. When employment opportunities are scarce, men should have priority in getting jobs over women

3. Girls/women who are harassed deserve it if they are dressed provocatively

\section{Household sphere}

4. A girl must obey her brother's opinion even if he is younger than her

5. Only the husband should decide on how household money is to be spent

6. A woman should obtain her husband's permission before doing anything

\section{Inheritance}

7. Even though Shari'a grants girls/women the right to inherit, in some cases girls should not get their share so as to keep the money/land in the family

Table A2: Attitudes towards domestic violence

\section{In your opinion, is a man justified in beating his wife in each of the following situations:}

When she burns the food?

When she neglects the children?

When she argues with him?

When she talks to other men?

When she wastes his money or spend it on trivial matters?

When she refuses to have sex with him? 
Table A3: Attitudes toward divorce

\section{In your opinion, in which of the following situations is a woman justified in asking for divorce/Khul':}

If her husband does not respect her parents or the elders in her family

If her husband does not listen to her or take her opinion into consideration

From the first time her husband beats her

If her husband beats her regularly

If her husband does not give her and the children enough money

If her husband wants to take her money or belongings

If her husband is in a relation with another woman

If her husband marries another woman

If she hates her husband

If the husband cannot have children

If the husband suffers from sexual dysfunction

\section{In your opinion, in which of the following situations is a man justified in divorcing his wife:}

If his wife does not respect his parents or the elders in his family

If his wife does not obey his orders

If his wife does not take care of the house well

If his wife does not take care of the children well

If his wife talks to other men (Literally: If his wife knows another man)

If his wife refuses to share her salary or a part of it for family expenses

If he hates his wife

If the wife cannot have children

If his wife suffers from sexual problems 


\section{Appendix 2: Full Text of Qualitative Vignettes (Arabic and English)}

\section{Education}

Laila is a 16-year-old girl. Laila's father agreed to her engagement to a man in his 30s, named Kareem, but Laila has heard that education is an important weapon in life and is good in her studies. Because of this, Laila refused Kareem, but her father is insisting that she marry.

a. What do you think of Laila's situation? Is she right or wrong, and why?

b. What do you think Laila's father should do?

Zeinab and Ahmed are a couple who have a boy and a girl, and don't have the resources to send more than one of them to general secondary school. Who do you think they should choose? Why?

\section{Family planning}

Hanan and Hatem are a couple with two little girls. They both work and raise their children together, but Hatem wants to have a boy and tries to convince Hanan to get pregnant again. Hanan is good at her job, and refuses the idea completely so that they can raise her daughters well.
a. What do you think of Hanan's situation?
b. What do you think Hatem should do?
c. In general, who do you think should make decisions about family planning? Why?

\section{Personal status law}

Hatem decided to marry another woman so that he could have a son, but did not tell Hanan. Hanan got suspicious and found out that Hatem got married again without telling her. She was angry and wanted a divorce. She went to a lawyer so that he could take the necessary steps to file for a divorce and other steps needed to get all her rights that follow a divorce.

a. Do you think Hanan has the right to file for a divorce? Why?

b. What are the rights that Hanan has in the case of divorce?

c. In your opinion, what are the difficulties that she might face during the divorce proceedings?

d. If Hanan does get the divorce, what are the problems she might face afterwards?

e. In your neighborhood, do you know of a case like Hanan's (a divorced woman)? Could you tell me about it? Did this woman face any challenges in her life or in the process of filing for the divorce? 


\section{Domestic violence}

Hoda and Kareem are a couple who have a lot of arguments, and in every argument Kareem beats Hoda. She has been used to this for a long time. One day her mother noticed the signs of the beating on her face, and asked her what happened. Hoda refused to tell her.

a. Do you think Kareem has the right to hit or curse at his wife, even if she was in the wrong? What are the situations in which a man can hit his wife?

b. What do you think Hoda should do? Did she do the right thing when she refused to tell her mother?

c. Do you think there are laws that prevent a man from beating his wife?

d. If such laws don't exist, do you think there should be a law? Why?

\section{Harassment}

Suha is a veiled girl who lives here in this neighborhood. One day as she was going to work, a man came up behind her and touched her, and as he walked away he looked at her and laughed. Many people saw what happened, but neither Suha nor any of the bystanders did anything.

a. What do you think of what happened to Suha? What should she do?

b. Why do you think the man did what he did?

c. What do you think of the bystanders?

d. Who is responsible in this situation? Who should protect girls from harassment?

\section{Inheritance}

El Haj Gamal is an old man who has three sons and a daughter, all of whom are married, and he owns a house and some land. One day the old man passed away, and his sons began to do the inheritance papers so that they could divide the inheritance between them. They prevented their sister from taking her part of the inheritance, and especially the land, afraid that her husband would inherit it in the future. They told her that she can take the profit from her piece of land but they will not give her the land or write it in her name. What do you think of the sons' position about distributing the inheritance? Is it within their rights to prevent their sister from taking her inheritance?

a. What do you think the sister should do?

b. What are a woman's rights in a situation like this? Do you think there is a law that criminalizes preventing the taking of inheritance? What is this law? 


$$
\text { ج- تفتكر في قوانين بتمنع الر اجل من أنه يضرب مر اته؟ }
$$

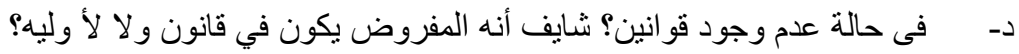

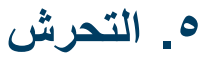

سهى بنت محجبة و عايشة هنا في منطقة زى بتاعتنا، و في يو و هوى رايحة الثغل، مشى و احد ور اها ولمسهاومشى و هو ماثشي

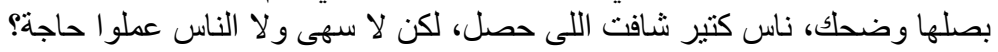

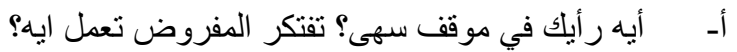

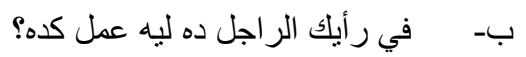
ج- أيه رأيك في موقف الناس اللى حواليكا؟ د- مين اللي مسؤل في للموقف للي حصل؟ مين مفروض بحمي البنات من التحرش؟

\section{7. الميراث}

الحاج جمال راجل كبير عنده ب و لاد وبنت، كلهم متجوزين، عنده بيت وأرض، في يوم من الايام توفى الحاج، وبدأ الابناء

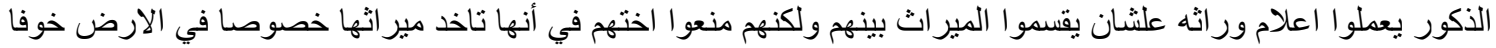

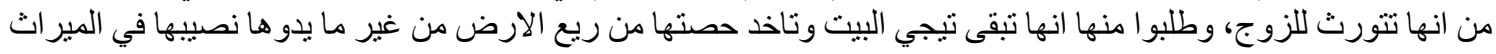
ويكتبوه باسمها. أـ ايه رأيك في موقف الابناء الذكور في توزيع المير اث؟ و هل من حقهم أنهم بمنعوا اختهم من أنها تاخد مير اثهر؟ ب- تقنكر البنت مفروض تعمل ايه؟ ج- ايه هي حقوق البنت في موقف زى ده؟ تفتكر في قانون بيجرم الحرمان من المير اث؟؟ وأيه هو ؟ 


\section{النص الكامل لاسئلة البحث الكيفي}

1 التمطليم

ليلى فتاة عندها ستة عشر سنة، قبل و الدها خطوبتها لرجل في الثلاثينات اسمه كريم، لكن ليلي سمعت ان التعليم سلاح مهم

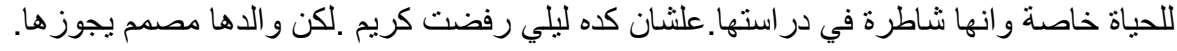

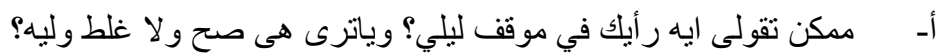

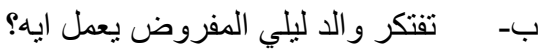

طب وزينب واحمد زوجان عندهم بنت وولا ومعندهم غير ان واحد بس فيهم يدخل ثانوية عامة .تفتكر هيختاروا

مين؟ وليه؟

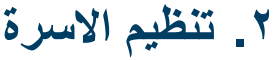

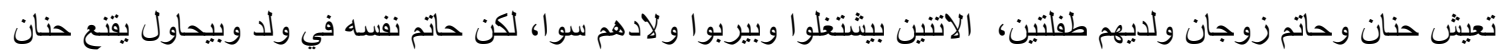

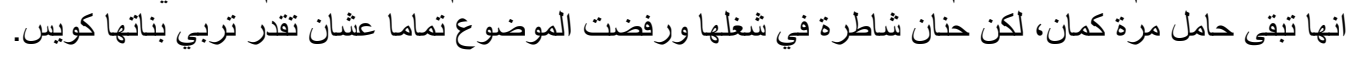

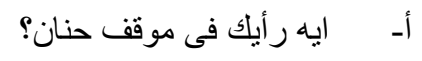

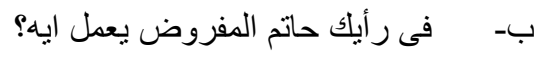

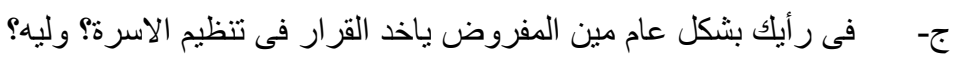

\section{ب. - مسائل الاحوال الشخصية}

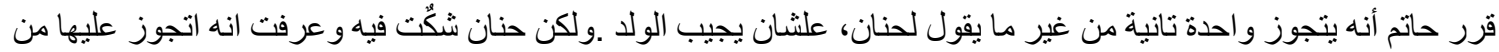

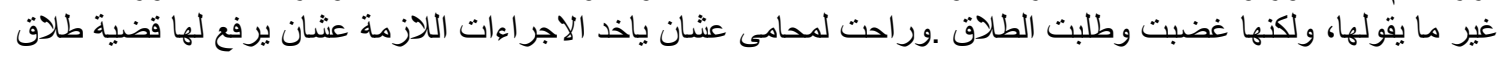

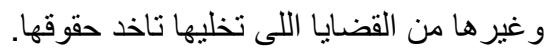

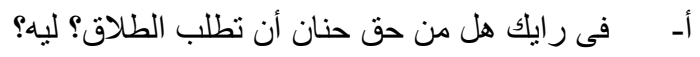

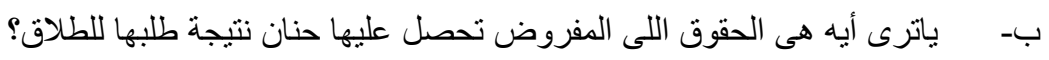

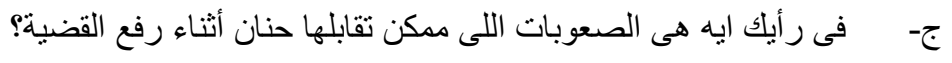
د- لو اتطلقت ابه المشاكل اللي ممكن تو اجهـا بعدين؟

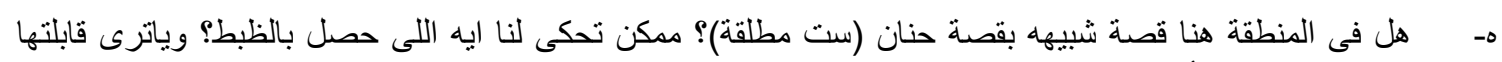
مشاكل في حياتها أو فى اجر اءات التقاضئ

\section{ع. ـ الضرب و الاهانة}

هدى وكريم زوجان دايما بتحصل بينهم مشاكل وفى كل مشكله، كريم يضرب هدى ولى واتعود على كده من فترة كبيرة، وفى يوم

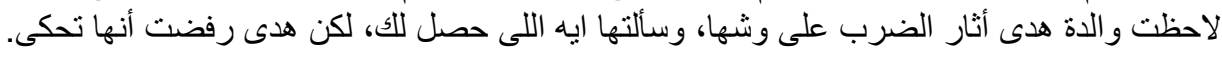

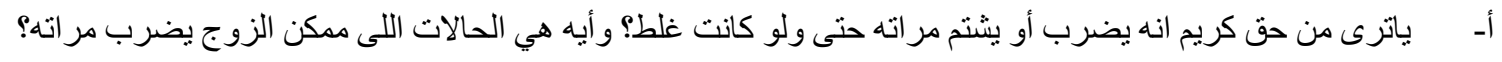

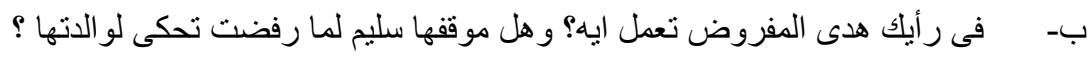




